UC-NRLF

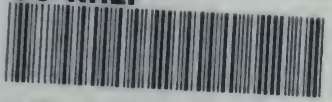
\$B 27? 673

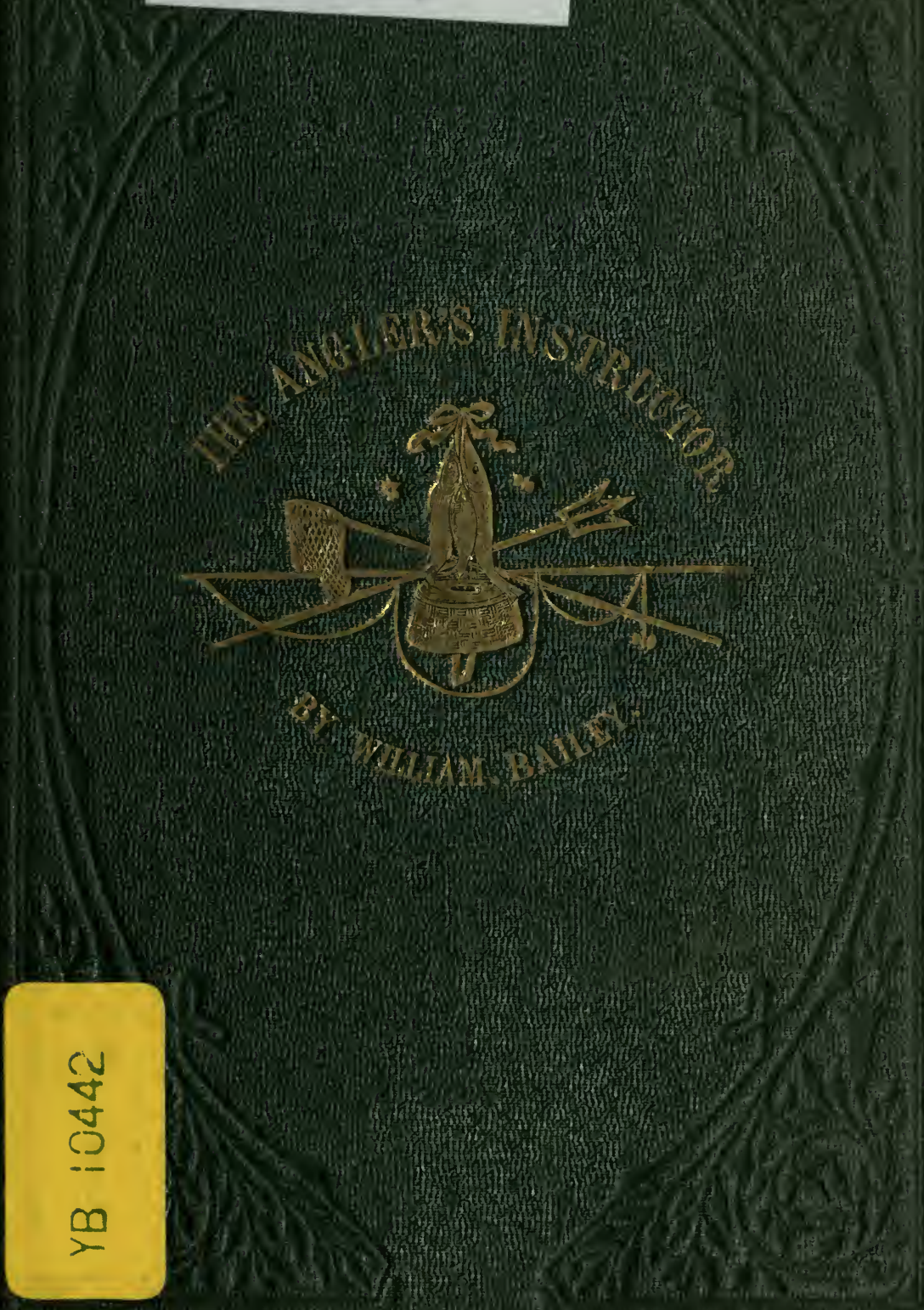




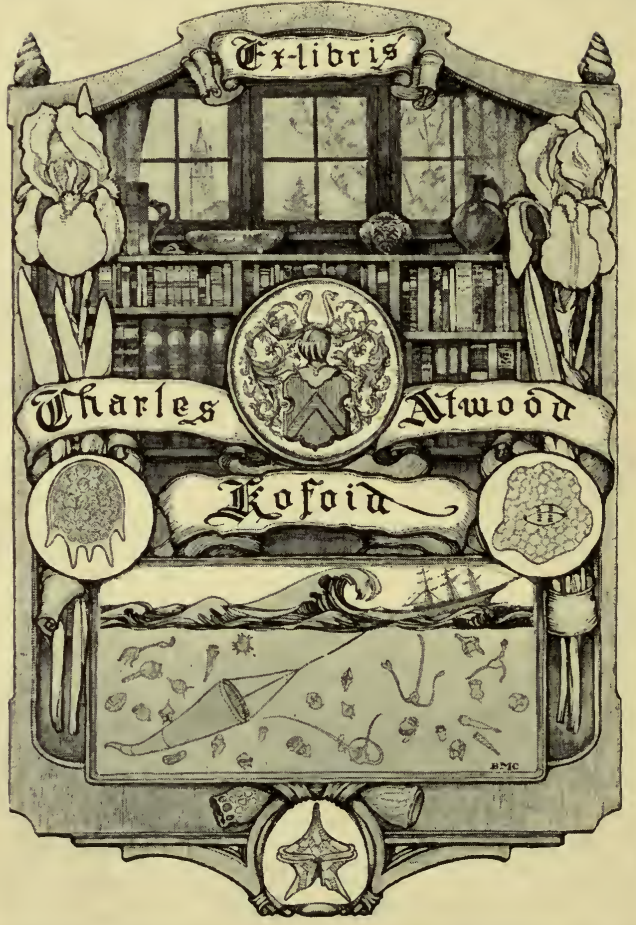




\section{A hoogen}

\section{THE LIBRARY OF THE UNIVERSITY OF CALIFORNIA}

PRESENTED BY

PROF. CHARLES A. KOFOID AND MRS. PRUDENCE W. KOFOID 


$$
\text { मेने ... को }
$$




\section{ANGLER'S INSTRUCTOR}

A TREATISE

A TREATISE

ON THE BEST MODES OF ANGLING

IN

ENGLISH RIVERS, LAKES, AND PONDS

AND

ON THE HABITS OF THE FISH

BY

WILLIAN BAILEY, NOTTINGHAM

LONDON

L O NGMA N A N D Co.

NOTTINGHAM

T. FORMAN, 14, LONG ROW 



\section{S'H605 \\ B25}

\section{PREFACE.}

SiNCE the days of good old Izaak, the common father, figuratively speaking, of all piscators, the art of Angling has improved to such a degree that his "Complete Angler,"-although it does, and shall ever, occupy a prominent position in English literature for the purity of its style-is not now regarded as a "guide, philosopher, and friend" in matters relating to the gentle craft. In fact, the book has long been considered as affording more amusement than instruction; and during the two hundred years that have elapsed since Walton wrote, many works have appeared to correct the errors which he fell into, and to disseminate, what the writers conceived to be, a better and more reliable knowledge of the art. In the belief that many of these have promulgated unsound views, and that the piscatorial directions given by them are generally erroneous, I have ventured to submit to the public, 
in the following pages, the opinions which, after upwards of twenty years practical experience as an Angler, I have formed as to fish and fishing. I have, indeed, made it the business of my life to study the habits of fresh-water fish, and to devise the best means of Angling for them at all seasons of the year, and in every condition of the water,-so that the sentiments which I have expressed in this work are not founded on theory, but based on long, careful, and diligent personal observation. Unfortunately, I am no scholar-I am but a "plain blunt man"-and make no pretensions whatever to having written in a pleasing and attractive style. If I have succeeded in making myself understood, I have done as much as I expected to be able to perform in a literary way.

I hope the contents of the book will be found to justify the title which $I$ have adupted for it. I have described the habits of the fish-pointed out their haunts at the various seasons of the year-the best baits to use for taking them, and when, how, and where they should be Angled for. I have shown what rods, reels, lines, and tackles should be used in Angling for the different fish ; and, in short, I have given such instructions, and laid down such rules as, I think, if attended to, cannot fail to make a good Angler of the most inapt scholar.

It will be observed that the Salmon is not among the fish that I have treated of. Although I have had so many years experience 
as an Angler, and have killed every fish of any note common to our rivers, lakes, and ponds, I have never had opportunities of fisking for the King of fresh-waters, and hence the want of any allusion to that fish in the following pages. Those who desire to become acquainted with the style of Angling for Salmon, cannot do better than consult the admirable treatises on this fish by "Ephemera," of Bell's Iife. With these few words I commit the "ANGLen's INstructor" to the favor of my friends, and, if I have any, to the merciful consideration of my enemies.

Nottingham, Ist Stptember, 1857. 
Digitized by the Internet Archive in 2007 with funding from Microsoft Corporation 


\section{CONTENTS.}

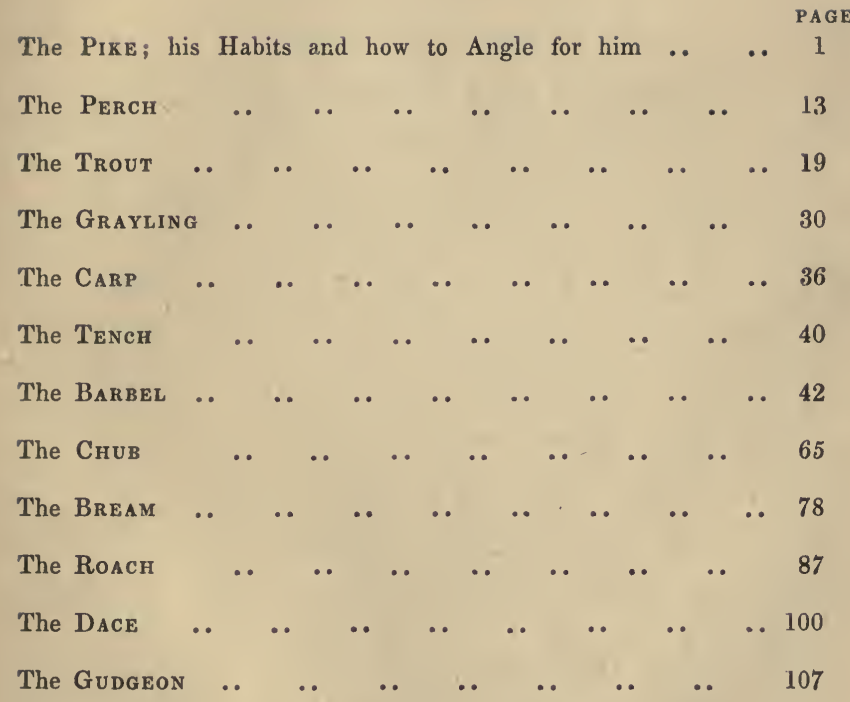





\section{THE PIKE.}

Prke spawn in March or early in April, and are out of season for three or four weeks thereafter, during which time they lie in a torpid state and refuse to bite. But they ought never to be angled for at that period as they are then unwholesome and unfit for food. While Pike are in this weak and listless cundition great numbers of them, I am sorry to say, are killed by" the net, snare, and gun-a practice which cannot. be sufficiently deprecated, and which no Angler could be guilty of indulging in. If $I$ had the power I would pass an enactment to prevent fishing for Pike in rivers in March, April, and May, and in stagnant waters in these months and June. Pike in still waters, such as lakes and ponds, take a longer time to recover from the exhausting effects of spawning, and it is on that account that I would give them a month's longer rest than I would such as can frequent streams. But, in fact, Pike caught in ponds are not at any time in good condition. If Pike caught in ponds could speak, I fancy they would address the owners somewhat in this fashion:-- "It is cruel of you, gentlemen, to keep us continually prisoners in this abominable stagnant water, when thousands of our fellow fish are enjoying themselves in the pleasant streams. We have scarce anything to eat, and only the same dirty muddy water to drink over and over again; and, of course, we get long and thin, and lose our flavour. Then the Angler comes, and when we are eaught we are abused 
for being miserable ill-favoured things. It is you, gentlemen, who, by keeping us in ponds, out of which we cannot get to the streams, which so much tends to improve our condition, that have brought upon us a bad name."

Some writers relate wonderful stories about the size to which Pike grow, and the voracity of their appetite. Many allege that Pike will grow to the weight of seventy pounds or more, and that it is a common thing for him to swallow a duck for dinner, taking by way of dessert a few frogs, newts, and snails; rats and mice making a supper which he relishes. As to size, although I have seen thousands of Pike, I have never looked upon one weighing more than thirty-six pounds. The latter part of the statement cannot be disputed.

But enough of this, exclains the young Angler, what I want to know is how to angle for the Pike. Pray come with me for a day's Pike-fishing to-morrow.

Professor.-Well, I will have a day with you to-morrow. Having studied the habits of the Pike during every period of the year, and having had twenty years practical experience as an Angler, I flatter myself I will be able to teach you how and when he should be fished for.

*

Pupil.-Well, here we are, and here are the Pike; I can see them in shoals. We shall have good sport to-day, I warrant.

Professor.-Stop, my young friend, you must not get on so fast. I admit you can see them, but neither you nor I can eatch them by fair means, and foul means do not become an Angler. I have merely come with you to-day to show you that fishing for Pike now is useless.

Pupil.-Why will the fish nut bite?

Professor.-This day is the first of April-just the time of the year that Pike deposit their spawn and will not bite. They leave the deep waters at this season and run up dikes, small streams, backwaters, and shallow places, for the purpose of generation, and deposit their spawn among the reeds over 
which you now see them. In this state they are, of course, exposed to much danger, and cowardly fellows taking advantage of their inertia, destroy them at this period in large numbers; but the Angler will lay by his rod for six weeks or a couple of months, by which time the fish will have got into good condition, and will afford good sport.

Pupil.-Then, the proper time to commence fishing for Pike will be ?

Professor.-Eight weeks hereafter. You might induce a few to bite in six weeks hence, but they will be scarcely in prime condition before two months. But, of course, if you fish for them at the end of that time you must look for them somewhere else, for they will be gone from here. They only visit these shallows for the purpose of spawning.

Pupil.-Then where shall I be most likely to find Pike when I go a-fishing?

Professor.-Pike leave their spawning places in May, and betake themselves to the streams to clean themselves. Where you find a sharp stream three or four feet deep with a rest, or a conjunction of two streams with a rest between them, or a shallow still water with a gravelly bottom and a little weed, by the side of a stream, there you will find Pike in May and June. As July and August approach they will go more into deeper water-under weirs, and old trees sunk in water pools, with flags by the side. As a general rule, wherever you can find flags, reed, or cover of any sort, and a deep water, you will be sure to find him up till the latter end of October or beginning of November. Towards the latter end of summer he will occasionally sally out from the deeps and chase the small fry across the water on to the shallows, where I have often caught him and brought him home to save him the trouble of returning. About November he gets to the mouths of backwaters. He does not go up, but remains at the entrance in the still water by the side of the stream that runs past. This is a favourite resort of his during winter. In spring he makes again for the shallows to spawn. 
Pupil-Very good. What are the best description of days to fish for Pike?

Professor. - Never go Pike fishing when it freezes sharp. As soon as you wet your line it becomes as thick as a rope by becoming coated with ice, and your rings get stopped up. Besides, although some writers on Angling say Pike will bite well in such a state of the weather, I can assure you they are very much mistaken. In January and February, when the weather is open and a little sun shining, and the water clear, with a gentle breeze blowing, Pike will bite well. A calm still day is bad for Pike fishing at any time of the year, but particularly in summer when the weather is hot, but they may be taken on such days in the morning and evening. A good rough wind will keep them alive in the hottest weather. As a general rule, however, you can take great store of Pike in spring, summer, autumn, or winter, if the water is clear and rippled by a gentle breeze and the day cloudy.

Pupil. - What bait do you consider best for pike fishing?

Professor.-The baits used for taking Pike are very numerous, some Anglers preferring one kind and others another, but in my opinion a Dace of two ounces is the best, next the Roach, then the Gudgeon and the Witling or Bleak. The Dace and the Roach for live bait, Bleak for spinning, and Gudgeon for dead gorge or trolling. I always use a Dace when I can get one, as he is very showy and wears well as a live bait, and I am sure Pike will take a Dace before any other bait. Ail artificial baits are useless. I remember seeing a gentleman fishing for Pike with an artificial bait on as fine a day as could be wished for Pike fishing; but although he fished all over the water he never got a single run. He asked me if I could tell him the reason why he had such bad luck. I answered by giving him a few Dace and telling him to try over the same water which he had already fished with the artificial bait. He did so, and returned in an hour with five good fish. "Ah, fisherman," said he, "I am satisfied the artificial bait is useless wherever the natural one comes." 
Pupil. - What do you think of this rod of mine for Pike fishing? It seems a nice rod and cost me thirty shillings, but it makes my arms ache confoundedly.

Professor.--It may well do so. It looks more like the mast of a fishing smack than a fishing rod. Why, it can't be less than eighteen feet, and it is as stiff as a prop. I am very fond of Angling, but if I were compelled to fish with such a rod as that, I would soon tire of the sport. I have tried all sorts of rods, but I have found none equal to the one I make myself. It is twelve feet long, light and handy, and you may fish with it all day with ease. It is in four parts, two made of lance wood and two of red deal-the lance wood being, of course, used for the top pieces; the deal must be good and well seasoned, and then nothing in the shape of a fish can break it.

Pupil.-What do you think of this reel of mine? It is a brass multiplier and winds up very quick.

Professor.- Your rod and reel match very well. I once saw a gentleman angling on the Thames with one of those multiplying reels. He was Roach fishing, but happened to hook a Barbel about three or four pounds weight-a game fish. Well, off he went at a tangent, and I could plainly see what would follow, for the reel could not give out the line fast enough and easy enough for the fish, so snap it went,' and float, tackle, and fish were lost. You cannot have a reel too light or that runs too free. The best is a four inch common wood reel, varnished to keep the rain from swelling the wood-the only brass about it being the hoop for fastening it to the rod. Brass inside and out adds to'its weight and lessens its utility. To cast a long line you must have a free and easy running reel.

Pupil.-W Well, it appears neither rod nor reel will do. What do you say to the line?

Professor.-Your line is too thick, and made of silk and hair - a mixture that I do not approve of. I suppose if you were to hook a fish you would (depending upon the strength of your line) pull him out at once, nolens volens. But let me tell you there is neither art nor sport in that style of fishing. When a 
fish is once properly hooked, of course you can make hin secure if you have got a cable for a line; but, believe me, you can never angle well nor successfully with a thick line. You may require to throw your bait a great distance from you, and after you have done so you must play it in such a way as to tempt a fish to bite whether hungry or not; and, let me assure you, you can neither do the one nor the other with a great stout line. A line made wholly of good silk, well plaited, is the best for Pike fishing. Fifty yards of such a line ought to weigh no more than three quarters of an ounce; and if it is well made you can kill with it the largest fish that swim in fresh water.

Pupil.-One question more, good fisherman, and then I go. What tackle is the best to use for Pike fishing?

Professor.-Take your time, my young friend, I have not done with your initiation yet. There are many kinds of tackle used, and Anglers differ very much as to which is best. Many allege that the dead gorge, or trolling tackle, is the most killing, but that is mere "bosh," and those who hold that opinion are very much mistaken. The principal Pike fishing tackles are:

The spring or dead snap,

The dead gorge or trolling,

The saddle or live snap,

The live bait or gorge,

The spinning or dead snap,

and

Single hook spinning.

I have tried and proved all the above, and my opinion is that the best of the lot is the spinning or dead snap; the next best being the live bait or gorge. These two kinds will be found to surpass every other description of tackle invented for capturing Pike. Many Anglers will, I know, be unwilling to concur in my opinion; but I will just relate how I convinced a brother of the angle of the correctness of my belief. Taking a fancy for a day's Pike fishing, I started off for the river with my rod in my hand and a few dead baits in my pocket. The wind was to my mind, and the water was in fine condition. 
I speedily commenced work, and in a cast or two hooked and landed a very good fish weighing seven pounds. Just as I had done so, up came my friend. "That's a fine fish," said he, "I have fished down all this side of the water, and have not had a single run. Would you have any objection to my accompanying you ?" "None whatever," I replied. So we both started together, and in a short time I landed three more fish-one five pounds, and two three pounds each. "How is it," he said, " that although I throw in the same places with you I never get a run?" Now, my friend was trolling or dead gorge fishing. There was a sharp stream, and over the stream a rest, in which place the fish lay. He threw his gorge into the still water, but while he was permitting it to sink a little the current pressed on the line and dragged the bait away before he had a chance of working it. My tackle was spinning or dead snap, which can be worked attractively the moment the bait drops into the water, which cannot be done with the dead gorge. I recommended my friend to put on a spinner, which I lent him, and at the second throw he killed a fish of six pounds. "Ah," said he, "I see; no more dead gorge for me. I always thought trolling was the best mode of fishing for Pike, but I see I have been wrong, but I shall be wiser for the future." Yes, dead gorge is the old style of Pike fishing, and a very indifferent style it is. It may do very well for bobbing about the side among weed, but something on a more improved principle is required for fishing at a distance in a river. My two favorite tackles are made in this style:-The spinner is twenty-eight inches long, made of gimp, not too stout; two treble hooks and lip hook; the bottom treble hooks are eleven inches from the first swivel, there being seventeen inches from the first swivel to the top of the tackle; the distance between the top of the lip hook to the bottom of the treble hooks is four inches, but you can have two or three different sizes so as to suit large or small baits. The live bait tackle is eighteen inches long, also made of gimp; two large hooks and a small one brazed together, the lead in the middle and the swivel at the top. As gimp is very bright 
when new and shines very much in the water on a sunny day, you had better, before using it, hang it outside for a few days. Exposure to the air will give it a pale brown hue, which is preferable to a bright glaring colour.

Pupil.- Now, I suppose I know all that is necessary to enable me to commence Pike fishing?

Professor.-Not quite. For live bait fishing you will require to use a float. A cork float is the best for that purpose, and it must not be in the bung shape, but cut long and thin and nicely smoothed. I would recommend you to take a landingnet with you when you go a Pike-fishing. Many a good fish has been lost for the want of this useful article. If you can't fish from the bank anci. wish to keep dry feet, put on a pair of water boots. When buying a fish basket take care to get one large enough, for it is a bore when you catch fifty or sixty pounds weight of fish to have no place țo stow them in. Take a bite and a drop with you when you go out, for your stomach's sake; but do not eat and drink too much else there will be little sport. And now, my young friend, you can be off to the water as soon as you like. When you do go out for a day's fishing make a day of it, and be not daunted at the first or the second failure; fish here, there, and everywhere, and persevere so long as there is a moment of daylight rather than come home with an empty basket; and, let me beseech you never to lose your temper at the little difficulties you may have to encounter; the learning how to overcome those difficulties will enable you to attain to a knowledge of the art, and by-and-by make you a good Angler.

\section{THE ART OF ANGLING FOR PIKE.}

If any one expects to be here informed how to capture Pike by foul and ungentlemanly means, he will find himself very much disappointed. I am surprised so many writers on angling not only make mention of the various snares used for poaching pike, but also accurately describe how they may be made and put into use,--a piece of information that, I feel assured, no 
disciple of Isaak Walton will thank them for disseminating. I have no respect for the man who can brutally and cowardly kill this excellent fish by means of the snare, trimmer, net, and gun. I am, I hope, a true Angler, and it is the fair and gentle art of Angling that I profess to teach, not the coarse and sanguinary method of massacreing fish.

The spinner is the best to fish with from June till October in rivers, but in ponds and lakes the live bait can be advantageously used occasionally. Lay out in some cold exposed place whatever dead baits you intend to spin with, so as to make them stiff and keep better on the hooks in the form you desire. Select the bait you think most likely, Dace or Bleak, and put the lip hook through both lips, and one of the first treble hooks in one of the shoulders, bending the bait a little at the same time; then take the bottom treble hooks and put one in at the tail on the other side of the bait, giving a slight curve in doing so to the tail. You are now ready for a cast. Select a place you consider likely, and throw the bait into the spot you desire to fish. I would here recommend the young Angler to fix a plummet or any sort of weight to his line and practice throwing at a mark. Let him begin at twenty yards and increase gradually until he can throw forty or fifty yards, when he will do. Well, having cast your bait as far as possible, allow it, if you are fishing in a pond, or lake or deep water, to sink a little, say two feet, then wind away at a brisk rate, holding your rod on one side rather low; if no run wind out and throw again, but this time wind brisk four or five yards, then all of a sudden stop a moment, then off again, doing so three or four times in one cast. I have often found this a good plan. If you still have no run try another throw and wind brisk as before, but occasionally giving your rod a sharp but short twitch. I have also found this an excellent method of using the spinner, but should it prove unsuccessful, here is another style: Throw as before, but on this occasion wind slow four or five yards, then with your rod drag the bait one or two yards sharp through the water, stop a moment and wind slow again; you will sometimes 
find when resuming the slow winding process that your bait is brought to a dead stop, which of course you must answer with a jerk of your rod. If you feel you have got a fish give him one or two more as quick as lightning, for you can seldom put the hook firmly in at the first strike. When you have got a run you will sometimes feel a sharp tug, but you will invariably be apprised of it by your line coming to a sudden stop, as if you had hooked a clump of wood. When you do hook a fish give him line, but keep one finger on the reel so as to preserve the line taut, and play him artfully. Do not use brute force as I once saw an Angler do. He had hooked a Pike which, from the rushes it made, I judged to be about twelve or fourteen pounds. I said, "Do not let him get away." "Why, it's only a fish," says he, "and I think I can pull as hard as he can." So at it they went pell-mell, now fish now fisherman, but only for a short time, for crack went the line and off went the fish, leaving the defeated Angler to exclaim, with an astonished air, "who would have thought it?" When spinning in rivers where there is a strong current, take care to wind very slow, otherwise your bait will be always on the surface of the water. You may kill more fish with the live bait than with the spinner in ponds and lakes at all times from July till February, but you cannot in rivers. From Oetober till February, when the fish have left the streams, and are in the still waters, the live bait is then, no doubt, the best. I consider November the best month in the year for Pike fishing; the Pike are then in better condition than at any other time of the year. On the 13th of Norember, 1856, I accompanied two gentlemen to a back-water on the Trent, and with two rods we succeeded in taking, with the live bait, in five hours, twenty-three Pike, weighing together one hundred and fourteen pounds - the largest being $10 \mathrm{lbs}$ weight. To preserve your live bait, you will require to keep them in a good sized bait tin, changing the water frequently, or what is better, put the bait tin into the water while you are fishing. They will keep stronger and more lively in this way than in any other. When you wish to fish with the 
live bait put on a cork float and live bait tackle. Take the small hook and remove a scale by the side of the back, or dorsal fin, at which place put the hook carefully in, but not so deep as to touch the back bone, which would kill the bait. Fix your float about two feet above the bait, if the water is from four to fire deep; and higher or lower according to the depth of the water. Cast your bait from your reel to a likely place. If you have not a run in the course of a minute, remove it two or three yards this way or that. Never allow the bait to remain longer than a minute in one place. When you get a run, the float will sometimes vanish as if shot off, but you must not strike when the float disappears. If the fish runs give him line slack from the reel. As soon as he has done running allow him a minute to gorge; then wind up the slack of your line and strike sharp, but not too hard, or you may cause a break. If you find you have got him strike again twice, sharp and quick, so as to make sure of having him fairly and securely hooked. By always adopting this plan I do not loose a fish out of twenty. Spinning the Minnow is considered by some people a capital mode of fishing for Pike. Indeed. I know several gentlemen who never angle for Pike with any other bait but the Minnow; using it either as a live or dead bait. I have myself had excellent sport with the Minnow. I have seen Pike snap the live Minnow as frequently as cast. In the summer months when the fish are in the streams, spin the Minnow in the same way, and in the same places, as recommended for spinning with the Dace; but your tackle must be lighter. A one-handed rod, twelve feet long, and not very stiff, is the best. As you have little weight to throw you must cast from the hand. Your line, which must be made of the best silk, must be finely plaited, and one hundred yards of it should weigh about three quarters of an ounce. Your tackle must be made in the same form as that recommended for spinning the Dace with ; but instead of gimp use Spanish gut. Here is an explanation:-Take two lengths of stout gut, join them, and put a swivel and small lead in the middle, and a swivel at the top. Lap your bottom gut five 
or six inches up, with fine tinsel, before you tie on the hooks, so as to prevent the Pike's teeth coming in contact with the gut. Let your hooks be small, say No. 8. There is another tackle made for spinning the Minnow, which I think is preferable to the above. It is made thus:-Take two lengths of gut as before, put the two swivels and lead on the top gut, and tinsel five or six inches of the lower, next the hooks. Make a noose at the top end of the gut large enough to allow the Minnow to pass through; tie a single hook on, say No. 1, and take a baiting needle and fix it to the noose, then put the needle in at the end of the tail on one side, and bring it out at the mouth, drawing the shank of the hook inside of the bait, and causing the bend of the hook to bend the tail; put the noose through the swivel, and the Minnow through the noose, and draw up. This, in my opinion, is the best tackle for spinning the Minnow with. You must strike as soon as you feel a run. You will require a quill float on your line in fishing with the live Minnow. A large turkey or swan quill float without cork is the best. Your tackle must be made of two strong guts joined together, tinsel at the bottom, and a small lead in the middle. No swivels are required. A single hook, No. 2, put in at the mouth will do; or you may use a No. 2 hook with a small one, No. 9, tied to it, and put under the back fin. When you get a run with this tackle, half a minute is quite sufficient to give the fish before striking. Fish with the live Minnow for Pike in the same places as I have recommended fishing with the live Dace. 


\section{THE PE R H.}

PERCH cast their spawn at the latter end of April, or beginning of Nay, and ought not to be fished for until the latter end of June, or beginning of July. I have taken them, however, in good condition early in June, when fishing for Bream with the worm. Three or four weeks after spawning, Perch are very voracious, and will run at anything; no matter what it is, or what you are fishing for, if it comes within his sight, a Perch will greedily seize it. They deposit their spawn amongst weeds, and in shallow spots with gravelly bottoms and weeds rear. In fact, they resort to the same places as Pike do to spawn. I have seen them in hundreds in places which I knew to be regularly frequented for spawning purposes by Pike. But Perch are more wary than their big friends, and will not venture to run up every dike, or small stream, that comes in their way as Pike will do. I have seen them, indeed, in rivers spawn in spots that I knew to be good places to fish for them. But in ponds and lakes Perch always seek the shallowest parts with weeds for spawning, and atter the operation is over, the deeps and shallows are alike. But in rivers this is not the case. After remaining where the spawn is deposited they go to the streams, where they stay for a short time, say in June or July. They then make for their regular haunts, under weirs, and by the side of sharp streams, where there are flags, and a deep heavy current; but at the end of summer they seek stiller, but not 
still, water, where there are flags and reeds; or a gravelly bottom by the side of willow beds, trees, bushes, or anything that will afford cover. From October till April Perch will be found in such places as I have previously mentioned Pike resort to in winter; except in the depth of winter, when they like a sandy bottom. The months for Perch fishing are July, August, and September; but I have caught them very freely in March, and in the beginning of April. Perch seldom bite in sharp frosty weather; but when the weather is open and mild you may take Perch, more or less, all through the winter. I have seen them bite well on a still misty morning in summer; but as a general rule, a dull day, with a gentle breeze blowing, is the best for Perch fishing. They do not fancy feeding on bright sunny days.

The rod for Perch fishing should be made light and handynot stiff as some Anglers prefer. The best is a light rod, twelve feet long, that will hit sharp from the top; every joint of which, when a fish is hooked, will take a proportionate share of the labour. In fact, a Roach rod is strong enough to kill a Perch. There is nothing so formidable in a Perch that you should require a rod as stiff as a prop. The rod which I use is just a light Roach rod. I have killed Perch from three to four pounds weight with it, and I have no doubt I could land with it the largest Perch that ever swam, and never fear a break.

I would recommend a three-inch common wood reel for Perch fishing. Generally speaking, you do not require so much reel work for Perch, but it is well to be prepared for anything that might happen. If, in some rivers that I know of, you were spinning the Minnow for Perch, a Trout eight or ten pounds might pay you a visit, in which case it would be all over with you unless you had a good and free running reel.

Your line for spinning the Minnow should be made entirely of silk plaited, one hundred yards of which should weigh about half an ounce. This is a good fine line, but the line for bottom fishing must be much finer, and one hundred yards should only weigh a quarter of an ounce. Of course, if you hook a fish 
with this line, you must not attempt to throw him over your head, else you will break it, but play him carefully. This is the line I always use myself for bottom fishing, and $I$ find it to answer admirably.

The same tackle as I have recommended for spinning the Minnow with for Pike, must be used for spinning for Perch, as you will take them both in the same water, and often as many Pike as Perch. But if you should hook a Pike you must be careful that he does not break your line. Gire him line and allow him to go where he likes, and he will soon exhaust himself, and then you can draw him carefully to the landing net.

The tackle that I have recommended for fishing with the live Minnow for Pike will also do for Perch, but the hook smaller, say No. 4 instead of 2 . Some Anglers use the Paternoster tackle and laud it very much for Perch fishing, but I do not myself think much of it. I have seen the two tackles worked together, and while the live Minnow with the float was catching both Perch and Pike, the Paternoster failed to get a bite. I thought, on first seeing the Paternoster, that the chances were three to one against the float; but experience has shown that my first impressions were wrong. The baits for, Perch fishing are very numerous: Minnow, Gudgeon, Loach, small Dace, worms of all sorts, gentles, wasp-grub, cadbait, straw-baitin fact, I once caught a brace of Perch at one cast with the fly - the red, or cockshackle, and peacock body ribbed with gold. But I do rot recommend fly fishing for Perch. They will take almost any kind of bait in the summer months. I once saw a gentleman take a Perch with an artificial Minnow made from a piece of plum cake, but I would not recommend this as a good bait. Taking all seasons of the year the Minnow and worms are the best, but the worm will kill more Perch at all times of the year than any other bait. The best kinds of worms are the cockspur or red worm, and the dew or lob worm. If you use the latter bait, fish with the tail end of a female lob. Some Anglers prefer the brandling and marsh worm, and various others, for which we have no name, but I have tried 
them all, and in many rivers and ponds, but found none to equal the cockspur and dew worm; and when properly used they certainly are the best.

\section{THE ART OF ANGLING FOR PERCH.}

Some Perch fishers think that nothing is too stout and strong to Angle for Perch with, and, indeed, sometimes they will bite at every cast be the line ever so thick; but this is not always the case. When the water is clear and the sun very bright, I have found Perch difficult to get at, and I would advise the fisher always to go cautiously to work and to keep still on the bank, for fish are more sensible of shakes than is imagined. July, August, and September are the best months for fishing with the Minnow, and the same style may be adopted and the same places fished as I have recommended Angling with the Minnow for Pike. For worm fishing put on your finest line a quill float (never use a cork one), a very fine gut tackle one yard long, and a No. 6 hook. If you fish in a pond or still water let your float be small; in a stream use a larger one. Before you go to angle for Perch bait the hole you intend to fish with three or four hundred dew worms cut in bits about an inch long, but do not mix them with anything. If you are going to fish in the morning bait the place the morning before. Never bait at night if you are to fish in the morning. I always allow twenty hours to elapse after baiting a place before I go to fish it. Get your depth the morning you bait, and measure it on your rod, so that when you come to fish you can adjust your line for the proper depth at once. But perhaps the reader may say, "How can I ascertain the proper depth ?" Well, I will tell him. The Londoners use a plummet, but they can only plumb the depth as far as they can reach with their rod. Now I can (and I will teach you how to do the same) find the right depth fifteen or twenty yards from the bank. Shot your tackle just enough to sink your float all but a quarter of an inch, and let the bottom shot be a foot 
from the hook. Put your float as low on the tackle as you can and throw into deep water. Notice particularly how much of your float stands above the water, then go to the place you intend to fish. If it be a pond or still water proceed thus : "It looks deep," you will say. Well, fix your float on chance at four or five feet and throw in; if it sinks to the place it was when shallow (that is, all but a quarter of an inch) you may conclude the water is deeper. Alter then your float until such time as it rises-which it will do as soon as your shot touches the bottom-and then lower the float a little bit until it stands the way it did when shallow. You can find the depth in a stream in the same way, only when your shot or bait touches the bottom in a stream your float will sink. When it does so alter it back until it rides the same as it did when shallow. This is a matter I would particularly call your attention to, because it is no use fishing unless you have the proper depth. Never fish on the bottom, but let your bait just miss it. Before you commence fishing you should throw in a few worms cut very small. If a still water throw them straight to the place you intend to fish: if in a stream throw them above where you intend to fish, calculating how far they will swim before they get to the bottom, for wherever your worms go your bait must follow, or you will catch no fish. This is one of the greatest points in Angling, and a point that has puzzled hundreds of Anglers, and when they get home they say they have had very bad sport to-day - that the fish would not bite, or the wind was in the east, or the sun was too bright, or the water too thick, or the wind blowing in their faces, or the weather too cold, and such other excuses as Anglers generally make when they have had no sport. But let me tell my good friends that they have not been Angling at all. They put their rod together and put on a line, and bait their hooks and fling it into the water, and they have thrown in some sort of ground-bait, but they never dream where it has gone to. Well, there they are, depending on their patience and good luck, but thinking it strange that the fish won't bite. Stupid people! Their tackle is twice as 
thick as it should be-their bait is three feet from the bottom, and their ground-bait has gone down the stream twenty yards and the fish with it; and there they are grumbling that the fish will not bite. The day is a beautiful day for Perch fishing, but they have not been fishing in the right style. I hope that I have given them a lesson, and I am sure whoever wish to go a Perch fishing will always be successful in filling a good basket if they will carefully attend to and observe the rules I have laid down. 


\section{THE TROUT.}

The Trout is a fine fish, nearly allied to the royal family, and excelled only by the Salmon, the King of fresh water fish. $\mathrm{He}$ affords choice sport to the Angler, being a determined game fellow, and when hooked will fight so long as a particle of strength remains. He who angles for the Trout will require to make use of all the skill and ingenuity which he possesses, for he has a fish to deal with that is cunning and sagacious, and difficult to get at. A friend of mine once said to me when we were about to commence fishing in a small Trout stream, "now for a bit of foxing." He knew well what a sly little fellow we had to deal with, and that we would require to make use of that characteristic of the fox before we could capture him. I am quite of my friend's opinion, and believe that no other fish requires to be angled for with greater art and tact than the Trout.

Trout deposit their spawn in November, but I once caught a Trout full of spawn on the 5th of December, but I believe it to bave been a late fish. November is, however, their proper time for spawning, and it is a proof of the extreme hardiness of the fish that they should spawn as it were in the middle of winter, living in their weak and sickly state in December and January, the two coldest months in the year. I scarcely know a fresh water fish that does not forsake the sharp streams in winter and retire to the stillest places they can find, except Trout. 
They delight in the strongest streams they can find all the year round, with the exception of spawning time, and the first fortnight or so after. They seek a gentle stream with a gravelly bottom to deposit their spawn. After this operation, Trout are sick for two or three weeks, and do not much alter their position until they have acquired a little strength, when they remove to shallow sharp streams, with a gravelly bottom, where they scour and cleanse themselves. After this they will have nothing to do with still waters, but get to the strongest and most rapid currents, under weirs, where the water rushes down in torrents, or any rapid stream boiling and dashing against banks or walls, - no water is too rough for the Trout.

As I have said already, the Trout is a fine fish, both for its edible qualities and for the sport which it affords. I know several streams where Anglers discontinue Trout fishing at the end of August, which I think is quite right; but they do not commence fishing till the first of May, thus allowing Trout eight months to be out of season. There is no need for all this waste of time. I have caught Trout in good condition at the latter end of February, and in March and April in prime condition. I feel satisfied the Trout fisher misses two of the best months in the year, if he permits March and April to go by. This is particularly applicable to rivers in which, without doubt, these are the best months for spinning the Minnow for Trout. I see, indeed, no good reason why Trout fishing should not commence in February, say in the middle of the month, and I am sure, even at that early period, nineteen out of every twenty Trout, taken from rivers and streams, would be found in good condition. The baits for Trout are very numerous, and the best can only be spoken of when speaking of a particular time of the year,- the best at one period being the worst at another. But I shall say what, in my opinion, are the best baits, and the time of the year when they should be used. The Minnow, small Gudgeon, small Dace, artificial and natural flies, worms, wasp-grub, gentles, straw-bait, cad-bait, and various other baits, are used for Trout fishing; but taking all times 
and seasons into cousideration, I believe there are none so good as the Minnow, flies, and worms, properly used, and each in its proper season. I have tried every description of bait used for Trout fishing, but I have found none equal to these three.

The artificial Minnow is used very much in some parts of England, and considered by many to be a killing bait for Trout. Indeed, I know several fishers who angle with no other bait for Trout, and who are perfectly satisfied that it is the best that can be used. So strongly convinced are some of them of this, that I would defy the best Trout fisher in the world to reason them out of their belief. Having two or three times in their lives killed a dish of Trout with the artificial Minnow, they think there is no other bait like it; but as a certain writer on Angling, whose reputation is likely to be ephemeral, would say, this is " bosh." If these thick-headed, opinionative gentlemen were fishing with the natural Minnow on those days when they were angling with the artificial, they would have caught three where they only caught one. Reader, take my advice. Never fish with the artificial Minnow if you can by any possibility procure the natural one.

The best months for spinning the Minnow are February March, and April-that is, in rivers where Trout are found large, in which ease they are never very numerous. Odd fish may be caught with the Minnow all through the summer, but these months are the best for spinning. If preservers of small streams would commence Trout fishing on the first of March (which I think would be nothing but right), they would find that March and April are the two best months in the year for spinning the Minnow, and that the fish would be in good condition. I hope they are not afraid of the cold winds in March; if they are they cannot be true Anglers.

May and June are the best months for fly fishing. At the May drake Trout will rise boldly and quickly. I have seen them leap out of the water at this fly when it was several inches from the surface. As the May drake is difficult to imitate, I would recommend dibbing with the natural fly. 
This is a sure game, but it requires a good deal of skill. There are hundreds of flies which you may catch by the river sides, and at which the Trout are rising, that you can dib with. There are also artificial flies of every size and colour-the best are those that resemble the natural one. July and August are the best months for bottom fishing with the worm; but I have caught Trout with the worm, at times in May and June, but this was when the water was coloured, and when the fish, not being able to see to feed on flies, were obliged to grub on the bottom. Experience, however, has convinced me that July and August are decidedly the two best months for bottom fishing with the worm. When the water is discoloured $I$-have found that Trout take, the worm better than any other bait that is used.

The rod for spinning the Minnow should be thirteen or fourteen feet long, light and not stiff. As your line is light and your tackle fine, you are likely to break when you get a run if you fish with a stiff rod. Besides, Trout when hooked sometimes make tremendous leaps, and if he leap from you and and you have a very stiff rod, something must break. I have seen this happen many a time. There is no occasion whatever for a stiff rod; the only advantage of which is, that when you have hooked a fish of five or six pounds you can throw it over your head, a stupid plan that I have seen adopted by blundering fishermen who care nothing for rod or tackle.

The rod for fly fishing should be thirteen feet long, and light, but not too weak in the middle, a fault common in fly rods. I remember fly fishing for Grayling with a friend of mine on the Trent. He was fishing with a well got up, nice looking rod, which no doubt cost a goodly sum, but, unfortunately, it was too weak in the middle. The fish were rising fast with both of us, but for every one he killed I killed three. He could not understand how this was, and it was a long time before I could make him believe the cause, which was, as I told him, that his rod was too weak in the middle. A rod for fly fishing should be light, the lighter the better, if you can preserve strength and 
keep the action in the right place. I consider that there is no rod which requires so much skill in making as the fly rod. If you want a fly rod made rightly go to the man who is a good fly fisher; his practical experience will enable him to make a rod free of the faults that most rods bought at the shops possess.

The rod for bottom fishing should be thirteen feet long, and light, with the sockets one size larger than those of the fly rod; though for bottom fishing in general a twelve feet rod is my favorite. A large rod, however, possesses the advantage of enabling you to keep mòre out of sight of the fish by standing further back from the water. The reel for spinning the Minnow should be a common wood one, three and a half inches, and varnished or French polished. The same size will also do for bottom fishing, but a smaller one will do for fly fishing, say a two and a half inch size.

The line for spinning the Minnow must be made of silk and plaited, one hundred yards to weigh about three quarters of an ounce. There are several different lines used for fly-fishingsilk and hair, all silk, and all hair-but the one I recommend is made of all silk, plaited and prepared. This is the best line I ever used for fly fishing; it is strong, waterproof, and you can throw well with it. Those who have not tried a prepared line for fly fishing should give it a trial, and I am satisfied they will find it much better than any other. The line for bottom fishing must be made of all silk, either plaited or twisted; but I prefer the twisted, because it runs smoother and wears better for bottom fishing; one hundred yards of it should weigh a quarter of an ounce. This is a fine line, but it is no finer than will be required, as I shall explain by-and-by. The tackle for spinning the Minnow, if you are going to fish in a river where the fish are large, should be made of three stout guts, not tied together, but looped to three small swivels, one at each joint, and the bottom gut lapped with tinsel three or four inches up, and a No. 1 single hook with a small Minnow lead one foot from the hook. I have proved this to be the best tackle for spinning the Minnow for Pike and Perch, as well as Trout. But if you are going to 
fish in a small stream, or brook, where you know the fish are small, I should recommend you to fish with finer gut; you might have one or two tackles made especially for brook fishing. There are two ways of baiting this tackle; one way is to put the Minnow on as you would a worm, in at the mouth and out at the tail, and then bending the Minnow in what form you like; but the other is the neatest way. It is to bait with a fine needle, unloop the bottom gut from the bottom swivel, allowing the noose to be large enough to admit of the hook and the Minnow to pass through; take your baiting needle and put it in at the tail of the Minnow on one side and out at the mouth, drawing the shank of the hook inside the bait, and the bend of the hook to bend the tail; stitch the mouth up with a needle and thread, lapping the thread once or twice round the gut, to keep the Minnow in the position you want it; thus baited take the loop and put it through the swivel, and the Minnow through the loop, and then draw it up. There are several ways of making spinning tackle, but in my opinion this is the neatest and best. If you are spinning the Minnow for Trout in a river, fish under weirs, in the rapid water by the side of stone walls, or broken banks where the river comes dashing and boiling furiously, at mill tails, and all such places. But only fish these places when the water is clear. When you do fish in such parts, put an extra lead on your line, at the top of the tackle, to keep your bait down better, and to enable you to cast from the reel to what distance you choose. When there is a rise of water, and when it is a little discoloured, do not select places so deep and rapid, but fish in steady shallow streams, and work your bait much slower, or the fish will not be able to see it. When you see a likely spot for a Trout keep as much out of sight as you can, as Trout when feeding on small fry often lie within a foot of the surface, so that they can easily see you, and if a Trout gets but a glimpse of either you or the rod he is off in a moment. When fishing a shallow stream one lead will be sufficient. Spin the Minnow against the stream, and if the stream is deep allow the Minnow to sink 
three or four feet, and spin upwards. Throw your bait as far as you can across the stream, then down the stream; spin quick; then slow; then let your bait sink deep in the water without touching the bottom, and spin it to the surface; then spin across the stream with your bait not more than a foot from the surface; in fact, let your bait go through all the different novements you can think of, for I find it difficult to explain this part of the art on paper. I could explain more in five minutes with the rod than I could by writing in a week; but practice, patience, and perseverance will soon make you acquainted with the best method for spinning the Minnow.

Fly fishing is thought by many to be the best mode of angling for Trout, as it affords the greatest amusement and excitement both to the Angler and the looker-on, but this is a matter of taste; for my own part, I care but little what style I fish for Trout, whether fly fishing, bottom fishing, or spinning the Minnow; and I would advise the Trout fisher to practice all three methods, for each are best at different times, and if the Angler makes himself acquainted with the three different ways of fishing, he will seldom return home with an empty basket. The following dialogue which $I$ overheard between a fly fisher and a bottom fisher will illustrate the different opinions that exist on the two modes of fishing:-

Bottom fisher.-What does your fish get when he takes your fly?

Fly fisher.- Why, of course he gets the fly and all there is.

Bottom fisher. - And a very nice morsel he gets-a bit of feather and a bone without meat.

Fly fisher.-And what does your fish get when he takes your bait?

Bottom fisher.-Why he gets a worm, all meat and no bone, which is better than your deceitful fly.

Fly fisher.-You do not understand fly fishing, else you would not have so much to say against it.

Bottom fisher.-Yes, I do. I can fly fish as well as you, or any one else, but I do not like it; there is something so 
cowardly about it,-it is the worst deception the Angler can make use of.

Fly fisher.-Nay, the deception is good, and that is why I like it so much. You cannot alter my opinion about fly fishing, neither do I want to alter your opinion about bottom fishing, so I bid you good morning.

The above shows that the Angler should be allowed to choose that style of angling that takes his fancy most. Fly-fishing, in my opinion, is a delightful mode of angling - clean and pretty, and affording good sport when Trout are taking. Bright sunny days are bad for fly-fishing. In May and June, when the day is bright, morning and evening are best. On a cloudy day, with a gentle breeze of wind, Trout will rise all day, but the best time is from ten till two o'clock, or the last hour at night.

The water must be clear for fly fishing, the clearer the better, providing the day be cloudy. It is useless fly fishing when the water is thick; at such a time the fly fisher, if he does not understand bottom fishing, is beat. I never go out for the purpose of fly fishing but I take with me worms or Minnows,if the fly should fail, one or the other is sure to suit.

Flies for Trout fishing are very numerous, and the opinions of Anglers are equally conflicting, for out of one hundred different fly fishers no two will agree on the same point; each has got the best killing flies, and those of each are different; and so with the fly dressers. They will all tell you that they can provide you with flies that will kill Trout in any. river in the kingdom, and yet there will be no similarity between the flies recommended by any two. But the fact is, that different rivers require different kind of flies-those that may be good killers on one river may not catch a single Trout in another. I have often found this to be the case, and all fly fishers who are in the habit of fishing in different streams must be aware of this. I would, therefore, recommend the Angler to have a good assortment of flies, and, when he goes to a strange river, to seek out the nearest flymaker, who is, of all others, the best qualified to tell you what flies are the most killing on the water in his imme- 
diate vicinity. Should there be no fly dresser near, the best plan you can adopt is to catch one of the flies off the water at which the Trout are rising, and from your fly book select a set of artificial flies, resembling as nearly as possible the natural one in size, shape, and colour.

For FLy Fishing you will require a fine gut lash or casting line the length of your rod, on which put two, three, or four flies. I always fish with four, although some Anglers object to so many. Always fish with the sun before you, and the wind behind you. If it should be blowing in any other direction, you will be unable to cast your flies where you want them to go. Cast straight before you, allowing your flies to go with the current as long as you can, so as to imitate the natural one swimming down the stream. Take care to have your running line always clear, for if there is any impediment, and you happen to hook a good Trout, he will break your tackle to pieces before you can free your line.

Dibiring for Trout with the natural fly is very much practised in some rivers, and I have had some very good sport by dibbing. It is done in this way:-Use your fly rod and finest line, with two yards of very fine gut, and put on a No. 10 hook; then catch one of the flies similar to those at which the Trout are rising, and hook it under the belly; let the sun be in your face and the wind behind you; stand as far from the bank as you can, then drop the fly lightly on the water, and if a fish do not rise at it in a moment, lift it and let it drop again. If there is a fish about, it will not be dropped many times before it is seized. Be careful when you strike that you do not break your line. You may do good execution by poking your rod between bushes, or under trees, overhanging the water, but you must go carefully and quietly to work, or you will not have the shadow of a chance.

Bottom Fishing with the Worm is decidedly an excellent mode of angling for. Trout. I have caught Trout with the worm when the fly and Minnow could not capture a single fish; and when it is done rightly, it is not easy to beat worm fishing. 
For a bit of "foxing" take your worm, fishing rod, and reel, your finest line, a quill float, and a fine gut one yard long, and a No. 7 hook. Let your bottom shot be one foot from the hook: get some well scoured red worms, or cockspurs, with a few dew worms, and you have everything ready to commence. If the water is clear, and you are to fish in a brook, or small streain, the most likely places are under bushes, by the side of piles, under old trees overhanging the water, or anything that can form a cover for Trout. Sit down very quietly ten or fifteen yards above the place you have selected for fishing in; if it is shallow opposite where you sit, and then falls into a hole, all the better. Get the right depth by having a swim or two,you cannot plumb it as you sit too far from where you are to fish,--make a guess at the depth at first, and if you are not deep enough, put it deeper until your float goes under the water, then alter it back a little so that your bait will just miss the bottom; then cut two or three dew worms into bits about the size of peas, and throw them in two or three yards below you, if the stream is not very swift, and if the water is five or six feet deep, they will go to the bottom of your swim-just where you want them. Put your bait on, and throw it in, letting it go down the stream, and giving line from the reel; never mind the line falling on the water. When your float gets a good distance from you, it is very fine and light and will not sink, but lies upon the surface of the water; give line until your float is under the bushes, and the Trout will bite one after another without fear, and you can soon fish out all that are in the hole. I think I could have done it in half the time I have taken to describe how to do it. If you are unsuccessful there is something or other wrong. Probably you have not watched the course of the stream before throwing in your ground bait, and the current may have washed it under the bank amongst the rubbish, where it would be of no use ; or you may have thrown it too far out, and not sent your bait after it, or it may have gone down the stream out of your reach. You cannot pay too much attention to the way you ground bait. 
As I said before, wherever your ground bait goes you must fish, else you will have no success. I will explain my plan of ground baiting. I select a likely place, and then ascertain the proper depth, taking care not to be deceived by anything foul on the bottom, such as sticks, large stones, or branches of weed, by trying above or below to avoid such rubbish, and having got a level bottom $I$ throw in a quantity of ground bait-but not sufficient to satisfy all the fish in the neighbourhood, as I have often seen dóne, and which results in the fish refusing to bite the bait on the hook-and I calculate how far it will swim before reaching the bottom. If this does not take effect $I$ throw in a little more higher up or lower down, closer in or farther out, as I think most desirable. If this takes effect, I stick to the spot, throwing in but a little of the ground bait at a time, but doing so often. Then your want of success may have arisen from your not fishing the right depth ; probably your float keeps going down in one particular place, and you, believing it to be the bottom, alter your float, whereas it has only been a large stone, or a lump of something standing under the water, so that, having altered your float, your bait may perhaps be a foot and a half from the bottom. It is impossible to have good sport unless you keep an eye on the bottom as well as on the top.

You may worm fish for Trout when there is a rise in the water, and it is discoloured, and get better sport than in clear water, but you must then fish in the shallows. When the water rises Trout leave the deeps and take to the shallows. Where you can find two or three feet of water, with a gravelly bottom, you will most likely find Trout. Fish in the manner I have already described, but you can keep nearer the fish as they will be less likely to see you when the water is discoloured, and you can catch them quicker and better than you could having a long swim. 


\section{THE GRA Y L I N .}

"OH, you beauty," I heard a gent once exclaim when I was landing a Grayling about a pound and a half, "I wish I had you fried nicely in butter." The gentleman had a good idea of the excellence of the Grayling, and I think he is the most delicious of fresh water fish. He affords choice sport to the Angler, and when hooked requires great skill and care to land. $\mathrm{He}$ is a pretty fish to look at, and very excellent when well cooked,-in flavour, indeed, he surpasses the Trout.

The period when Grayling deposit their spawn is, I think, known but to few fishers. On the 18th of March of this present year (1857), I killed a brace of Grayling full of spawn quite ripe. I also killed a brace on the 20th, and saw one caught by another Angler on the same day, and all were full of spawn. I was determined to ascertain the proper spawning period, and went every day after to the water, when it was in condition for fishing, but caught no more until the 17th of April, when I got a brace and a half-two female fish and one male. I cut them all open and found the female fish had parted with their spawn, but a portion of milt still remained in the male. I also caught a brace on the 19th of the same month, both female fish, and free of spawn. I had thus satisfactory evidence that Grayling deposit their spawn at the latter end of March, seeking for that purpose a gentle stream not more than two feet deep, with a gravelly bottom, and a little 
weed. All the fish, I have mentioned as having been caught were taken with a fly, made of a dark partridge hackle, body copper coloured, peacock's harl ribbed with gold, on a No. 10 hook. I have had some very good sport with this fly, not only in spring but in the latter end of summer. It is a first rate killer on the Trent, but it might be a "duffer" on another river. There can be no harm in giving it a trial, however.

As soon as Grayling recover from spawning they make their way to the sharpest streams to scour themselves-not deep but shallow rapid water-where they remain from the middle of April to the middle of May. But small fish may be caught in this sort of water occasionally all through the summer. The larger fish, however, leave for a quick stream five or six feet deep, where they remain up to the end of November, when the frosty nights set in. They then retire to a gentle stream with a sandy or gravelly bottom, where they lie until spawning time.

The best months for Grayling fishing are August, September, and October, but November is also very good if the weather is open and fine. In the latter end of April and the beginning of May some very good fishing may be had with the fly. They will also take the cad-bait at this period pretty freely. This bait is yellow in appearance, and is found urder large stones on a gravelly bottom in April, May, and June, and is an excellent bait for almost all fresh water fish. Grayling will not rise at the artificial fly on calm sunny days; having a good eye he quickly detects the deception. A cloudy day with a gentle breeze of wind from any quarter (barring north or east) is at all times of the year the best. If the day is cloudy, from ten in the morning until two in the afternoon is best for fly-fishing; but if the day be hot and calm, morning and evening are the best times. In autumn and the winter months, if they rise at all, it will be only in the middle of the day. The water must be very clear for fly-fishing, the clearer the better if the day be cloudy. When the water is coloured there is very little chance of taking Grayling with the fly, and if you want to catch any then, you must bottom fish. When the water is thick you may take 
Grayling every month in the year bottom fishing. "The best baits for Grayling are cad-bait, straw-bait, gentles, wasp-grub, worms and flies. I have caught them with all these baits. The first bait they feed on after spawning, and the one they most prefer, if the water is clear, is the fly. Taking all seasons into consideration the red worm or cockspur, and flies are decidedly the best to fish with, perhaps the fly may be said to have the preference. Grayling certainly rise readily at the fly and seem to have a particular fancy for it. But if a first-rate fly fisher and an equally good bottom fisher were to contest, I should be inclined to back the bottom fisher for the greatest weight and the best fish. I, however, consider fly fishing the most delightful mode of angling for Grayling; the style is pretty, neat and clean, and when the rod is in skilful hands it is most exciting and amusing.

The flies for Grayling fishing are very numerous-so numerous that it would be impossible to describe them all. I could not profess to provide the best flies for every water in England, but if any gentleman came to me I could give him as good flies as can be got for fishing on those waters that $I$ am acquainted with. I have seen fly fishers quarrel like cocks about who had the best flies for Grayling. One would say I have proved mine and caught so many brace,- the other would say the same; and yet the flies of each would be differently made, and different in colour. I once fished, by way of experiment, with a set of four flies. Two were made very rough, and two were made as nicely as flies could be made, and resembling as near as possible the natural one on the water. Well, I killed five brace of Grayling with the two rough made ones, and only one single fish with those that were made so neat and fine. This experiment proved to me that fly fishers are more particular about their flies than the fish are.

\section{FLY FISHING FOR GRAYLING.}

Your rod should be twelve feet and a half long, and be made 
by a first-rate fly fisher, for he is the only person most likely to make a faultless rod. Your reel should be a common two inch wood one, and your line made of all silk, plaited and prepared. I prefer a prepared line to any other for fly fishing, because it is strong, waterproof, and light, and you can throw with it better than with any other. You may put on as many flies as you like; one, two, three, or four. I generally fish with four. Select the sharpest stream you can find-it can never be too rapid for Grayling-from two to four feet deep. Commence at the top of the stream, and fish it down. Cast your flies straight across the stream, allowing them to go along with the current as long as possible. Let your flies drop lightly on the water, and let your lash be perfectly extended and straight. When you get a rise strike gently. Some fly fishers prefer not striking at all, allowing the fish to hook itself, but I have seen many a good fish lost by this dodge. I recommend a gentle strike. Do not, when you have hooked a fish, keep him in too hard, as the Grayling has a tender mouth and might break away. Put on a gentle pressure, giving him line if he wants it.

\section{BOTTOM FISHING FOR GRAYLING.}

Your rod must be twelve feet long, and very light; a Roach rod, in fact, will do very well. Your line must be made of all silk, twisted soft. It must be very fine, and a hundred yards of it should not weigh more than a quarter of an ounce. Provide yourself with a quill float. Your tackle should be one yard long, and made of fine gut. The hook, if you are going to fish with wasp grub, cadbait, or any other sort of grub, should be a No. 9. If you are to fish with the worm, use a No.7. or No. 8 round bend. Let your bottom shot be 9 inches from the hook.

Select a likely place. If the water be a clear sharpish stream, from three to four feet of water will be a suitable depth; and if the water be coloured, two or three feet deep will be sufficient, and the stream must be much slower. Never fish a quick 
stream when the water is thick, as the fish cannot then see the bait. I have often caught Grayling two feet from the bottom, when the water has been clear. It is well known that owing to the position of the eyes in the head of Grayling, they see better above them than below them. You should not fish, therefore, on the bottom but a few inches above it. As a general rule, however, whether the water be clear or coloured, if you fish about two inches from the bottom you will be about right; but you must throw some ground bait in. If you fish with grubs of any kind, throw a few gentles in, not many at a time, but a few often. If you fish with the worm, you must throw a few in, cut very small. The dew or lob worm is the best for ground baiting, generally speaking; but for Grayling fishing I prefer a few small worms, or cockspurs (the same as I have recommended to put on the hook) cut in two. I have found this to be the most enticing ground bait for Grayling. Do not mix your ground bait with anything. All you have to do is to throw it four or five yards above where you intend to fish. Put your hook in at the head of a well scoured cockspur, and run it carefully till within a quarter inch of the tail. When a worm is put on well, it will writhe as if there is no hook in it; the better you put the worm on the more likely you are to catch fish. When you fish a quick stream always cast your line a little above, else your bait will not get down soon enough to the bottom, so that you may miss the best part of the swim. Let your float swim as still as possible, giving it line from your reel, taking a swim of ten or fifteen yards. When you hook a Grayling be not too rash with him, or you will loose him. As I have said before his mouth is tender, and you must be very careful. When fishing with the worm in this style, you must not be surprised to find a Dace or a Trout pay you a visit now and then; but whether you will be disgusted with such visits I cannot say. I remember seeing a real Grayling fisher angle in the above style. The first worm he put on killed a Grayling about a pound weight. I said, "you have made a good start." "Yes," says he, "this will do very well 
if I can do the same with this bait." Behold, master Dace takes a fancy to it as soon as it gets to the bottom. The Angler brought him in, took him off the hook, and flung, him into the water again, apparently very much annoyed. The next fish that came was a Barbel, two pounds weight, which he also returned. He then hooked and landed a Trout, about a pound weight, which he also sent home again. This so astonished me that I said, "Do you know what you have done? you have thrown a fish in again worth as much as your Grayling." "I do not care," he replied, "when I come Grayling fishing I don't thank any other fish to bite; in fact, I am disgusted when I see another fish come out." "Well," I said, "you had better pick them, it will save a deal of time and trouble; put on a bait that nothing but Grayling will take, and then you will be right." But, to speak the truth, I would sooner remain at home than be bothered with any other fish when I go after Grayling. 


\section{THE C A R P.}

CARP deposit their spawn in May in shallow retired water where there are weeds. From this time until July they are out of season and should not be molested. The Carp is a good fish, and should be well protected in its weak and unconditioned state. The best months for Carp fishing are February, March, and April, July, August, and September. The latter three are most preferable, as Carp will not bite in sharp cold weather. They are delicate fish and cannot stand the cold, for even in the hottest weather in summer they will not venture into the rapid water of rivers but remain in gentle streams. Carp can only be fished for in the first three months when the weather is fine and open; they will then be found in deep still water. Carp are fonder of ponds, lakes, and stagnant waters than rivers, and may be found in almost every pond in England, and in some they attain to a very large size. I know several ponds full of large Carp, but they are preserved, and those who angle for them do not understand the art. The Carp is shy and crafty, and the angler must be possessed of much skill and patience that can successfully fish the rascal. I know gentlemen who have the privilege of fishing these Carp ponds, but always with such bad fortune that they call the Carp "Old Fox." He will refuse all sorts of baits, and defeat every attempt to eatch him, and, apparently, glorying in his superior sagacity, will maliciously sport and leap around the boat, roll over the line, and defy the 
annoyed angler to capture him. I should like to see them jumping and rolling about me, $f$ could almost bet a wager that I would soon stop their sport. $\mathrm{He}$ is a cunning fish certainly and very shy, but he is to be caught for all that. I have not had the pleasure of fishing many Carp ponds, but I have fished them successfully, and will describe by-and-by my style of deceiving the rascals. The baits for Carp are very numerous, and the following are recommended by anglers:-Creed malt, wheat, straw-bait, wasp-grub, gentles, cad-bait, red paste, white paste, \&c., but in my opinion there is no bait, taking all seasons into consideration, that will catch Carp half so well as the worm properly used : the tail end of a well-scoured female lob worm is an excellent bait, but the cockspur or red worm is the best that can be used for Carp fishing. At all times and seasons when they will bite they will take either of the above baits, giving a preference, however, to the cockspur. The rod for Carp fishing should be twelve feet long, light and handy; it cannot be too light provided the action flies from the top and the wood be of a good quality. The reel, a three inch wood one; the bobbin to be filled three parts full with soft cotton or worsted and the line on the top. The line should be made of all silk, plaited or twisted, and should be so fine as not to weigh more than a quarter of an ounce per hundred yards. Rather fine this, perhaps you may think, but not a bit too fine for the gentlemen you have to deal with: what the line wants in strength you must supply with skill and judgment.

There is only one method of angling for Carp, and that is to bottom fish for him, and you will require a small quill float if the water be four or five feet deep; but if it be twelve or fourteen feet deep the float must be larger, or else your bait will be too long in getting to the bottom, and by the same rule alter your float when the wind blows wrong for throwing in. Your tackle should be four feet long, and made of the finest gut, stained in a decoction made from walnut hulks, which will dye the gut a pale brown. If you are fishing in a still water let your bottom shot be twenty inches from the hook; if in a gentle 
stream, let the shot be as near as twelve inches. The hook should be a No. 7 or No. 8 round bend. You will require four or five hundred dew worms and as many more cockspur or red worms, or any sort of red worm will answer the purpose instead of dew worms, perhaps better, as they would form the mixture I want. Take the stock and put them separately into pots with some clean moss. Those worms with which you are going to fish should be scoured for three or four days so as to make them brighter and tougher.

\section{THF ART OF BOTTOM FISHING FOR CARP.}

As I promised I will now explain my style of fishing. We will suppose the time is July, August, or September. I take my rod and tackle with me and about seven hundred of the thousand worms and start for a Carp pond or lake in time to get there by eight or nine o'clock in the morning. If I am a stranger to the water and have no person to show me the place the fish frequent, I tackle out and take stock of the water, endeavouring to find the deepest spot and clearest of weeds. If I cannot fish from the bank I get a boat and go carefully over the water until I find a suitable place. I then ascertain the depth, either by plumbing or without, allowing an inch or two for the bait to rest on the bottom: I then measure the depth on my rod so that I can arrange my float for the right depth on the following morning without disturbing the fish. I now take all the worms from the moss and cut the dew worms into two or three bits and mix the small worms with them: I then throw the lot into the place, and thus baited I leave it, marking the spot; I then either return home or spend the day on some other part of the pond, and if I think of doing the latter I take one or two hundred worms extra with me; but I take care not to go near the place I have ground baited any more that day. I return on the following morning after having allowed twenty hours to elapse since baiting, and bring with me the remaining three hundred worms. If I can fish in this place from the 
bank with the wind behind me so much the better, but if I cannot I must take a boat and take care to have the wind behind me, going no nearer than I am obliged, allowing ten or twelve yards to throw, which I can easily do with the fine line. Having secured my boat in the best way I can, I put on my float to the proper depth, which I ascertained the day before: I then cut three or four dew worms and small worms into bits no larger than horse beans and throw them into the place I have baited, keeping all the time as quiet and still as possible. I then proceed to bait my hook. I take two cockspurs out of my bag and put the hook in at the head of the first and out about a quarter of an inch from the tail and draw it up the gut; I put the hook in the other about a quarter of an inch below the head and run it on to a quarter of an inch of the tail, and I then draw the other worm down to it. This you will perceive is an attractive bait, and when I cast into the place I have baited a bite is almost certain as soon as the bait gets to the bottom. I do not strike the moment I perceive a tug, but suffer the fish to take the float under, then I strike gently; if I find he is a good fish I allow him to go where he likes: it would be useless trying to stop him; if I did something would be sure to break; his own exertion will in a short time knock him up; when it does pop the landing net under him and all is right. Every fish or two I kill I give them two or three worms cut very small, which keeps them together.

Now, I am convinced if all gentlemen who go to fish for Carp will but pay attention to the remarks $I$ have made, they will seldom return home disappointed. 


\section{THE TENCH.}

THE Tench is a beautiful fish, thick and well made, and considered by many Anglers to be as good as any that swims, and I think so too; but would like him better if he would forsake the muddy waters and take to a pleasant running stream; but this he does not seem to fancy, so we are obliged to take him as he is.

Tench spawn at the latter end of May or beginning of June, and, like the Carp, seek, for this purpose, the most retired places, shallow and full of weeds. Tench should be strictly preserved during these months. They are then poor sickly fish, and easily taken by the poacher's net. The best months for Tench fishing are July, August, September, and October, and sometimes in March and April, when the weather is fine and warm; but he never bites in the cold winter months. I believe he hides himself in winter either amongst the weeds, or in his favorite mud, for we cannot so much as get a glimpse of him in winter. When I can catch Tench in March I find them in first-rate condition, perhaps better than at any other time of the year, but he will rarely be persuaded to bite so early in the season. The best baits for Tench are worms, wasp-grub, cadbait, and gentles. I once had a very good day's sport in a pond with the wasp-grub for bait, and gentles for ground bait. I baited the place the day before with gentles: this was in the month of July. The wasp-grub and cad-bait are the two best 
baits you can fish with for Teuch the first month after spawning; but after that month the worm is decidedly his farorite bait, and will catch him better than any other,-the red worm or cockspur, and the female lob worm. The rod, reel, line, float and tackle, recommended for Carp fishing, will answer for Tench, only that the hook for wasp-grub must be No. 9, instead of No. 7 or 8 -the latter size being for worm fishing. You may bait the place with worms in the same way as recommended for Carp, and fish for them in the same style. Do not mix your ground bait with anything, but throw the worms in as clear when baiting as fishing: this is the only way to ground bait properly. Some Anglers mix up a fearful mess for ground baiting. I once saw a gentleman in a punt, on the Thames, mix up the following beautiful mess for ground baiting, half a tubful of which he threw in:-A quart of bran, two pounds of soaked bread, a quart of gentles, two or three handfuls of greaves, and two or three hundred of chopped dew worms, the whole of which he kneaded together in the same way as a baker would knead bread-his sleeves being turned up to his shoulders. This bait, instead of having the desired effect, produced the very opposite result. This ground bait has been recommended by some Anglers both for Carp and Tench; but I think it is absurd, and so I am sure will every sensible reader. 


\section{THE B A R B E L.}

THIs is a handsome well made fish, but he has got a bad name, in consequence of his coarseness, and many Anglers do not consider him worth fishing for. His flesh is certainly coarse, and bad food, but gentlemen Anglers do not fish Barbel for eating, they fish them for pleasure and sport, and Barbel is just the fish, when hooked with fine tackle, to give the Angler any amount of sport and excitement. When a Barbel is hooked with fine tackle it requires no ordinary amount of care and skill to kill him, and herein lies the delight of gentlemen Anglers. I know hundreds who prefer angling for Barbel than for any other fish. The great Izaak Walton was very partial to Barbel fishing, but whether he ate them when caught is another thing. But let me tell you who are so prejudiced against Barbel and Barbel fishing that you are "duffers"- excuse my freedom -for it makes me wroth to hear Barbel fishing run down by those who do not understand the art. For my part, when Barbel is in season, I would rather angle for him than for any other fish. So enamoured am I of Barbel fishing, that $I$ found myself once inspired to give vent to the following poetical effusionlisten and be edified :-

The Barbel is a handsome fish, As you may plainly see,

But that his flesh is very coarse, With me you will agree.

Yet fights he hard, and dies right game, And thinks of getting free,

But then he finds it is no go

When once hooked fair by me. 
Barbel deposit their spawn in May, under weeds, and in a gentle stream with a gravelly bottom. After spawning they lie in a weak, sickly, and torpid state for a week or two, but they should not be molested for a month. I am sorry to say I know that many are taken in this state by the net, spear, and other foul means ; but the genuine Angler would scorn to do this, and those who could be guilty of such cruelty ought to be severely punished. The Barbel, as soon as he has gained a little strength, makes his way to the sharpest streams he can find, to scour and clean himself. In the latter end of June or beginning of July, while he is in rapid streams, he affords the Angler first rate sport, but it requires a good stomach and a deal of patience to fish such places with the fluat. Towards the latter end of July, or beginning of August, he returns into deeper water, and remains there all the season excepting on bright hot days, and when there is a rise of water, when of course he takes to the shallow streams. Wherever you once find Barbel, if in a scouring place, you may catch them more or less throughout the season, till October, when the frosty nights put a stop to Barbel fishing in the streams. The only chance you have then is to fish the deepest water you can find; or wherever there is a shelving bank, or a deep cover of any sort, that will make him a home for the winter months. He will remain in such places up to March, unless a rise of water or flood comes to force him out against his will. My opinion is that Barbel lie in a torpid state in the coldest winter months, and feed but little, and I think it useless attempting to find out a bait that will catch him as well in winter as in summer. I have tried this for many years, but without success, and will now give it up and leave it for some one else to discover.

The best months for Barbel fishing are July, August, and September, and October if the weather is fine and the water clear. April is also a good month if the weather is fine and warm, and the water is low and clear. I have had some good Barbel fishing in A pril, and I have also taken them freely up to the 14th or 15th of May, but never later before spawning. But in the season 


\section{4}

in which I caught them so late, the months of March and April were very wet and cold, and I believe that in consequence they went a week or two past their usual spawning time. I have seen them on the scour as thick as they could lie on the 2 nd of May, but never sooner. There are numerous baits used for Barbel, but I shall confine myself to mentioning those which I use myself, and which I consider best at the different seasons of the year. The cadbait is good for Barbel fishing just before spawning time, and for the first two or three weeks when they can be fished for after. The cadbait, as I have elsewhere mentioned, is found under large stones, on a gravelly bottom, in April, May, June, and July. Maggotsand gentlesaregood baitsin some rivers, but do not take very well in the Trent. Greaves, cheese, and worms, I believe really to be the best baits for Barbel. The fittest months for greaves and cheese are August and September; the dew worm may be used almost at any time, and, in my opinion, you may eatch more Barbel, and keep them biting longer, with the worm, than with any other bait ever invented. This I have found to be the case in all rivers that I have fished.

The best method of fishing for Barbel is with the float. Some Anglers consider the plumb, or leger, the best style and the most killing mode of fishing, but I should have to talk for a long time before I could make my pupils believe this ; and all sensible people, and every pupil to whom I have divulged all the mysteries of angling, concur with me in thinking that plumbing is too slow and sleepy for the Anglers of the present day. There is as much difference between plumbing and float fishing as there is between the slow coach of bye-gone days and the fast railway car of the present time. My opinion is, that the plumb will be shortly shelved altogether, except for night fishing, or when the water is thick: these are the only times I should recommend the plumb to be used.

The Rod for Float Fishing should be twelve feet long, light, and handy, - one that you may fish with without tiring. The rod which I make myself is just the thing; I cannot see 
where I could improve it, or make one to answer the purpose better. I have made a great many rods of this description for those who approve of my style of angling, and they form, I am proud to say, a very numerous body.

The Rod for Plumbing must be thirteen feet long, and much stiffer than the one for float fishing.

The Reer for Barbel fishing should be a three and a half inch common wood one, varnished, to keep the rain from swelling the wood, without any brass about it, except the slide or hoop for fastening to the rod. The freer it runs the better. You should carry a small bottle of oil with you, and oil it two or three times when fishing.

The Line for Float Fishing should be made entirely of silk, twisted, one hundred yards to weigh about six drams; half an ounce line this length would be too thick.

The Line for Plumbirg should also be made of silk, twisted, and weigh about ten drams per one hundred yards. These lines are excellent for Barbel fishing, and when in skilful hands are strong enough to land the largest Barbel that ever swam. The following anecdote will show how some people condemn the lines and tackle as being bad when they break, instead of ascribing the breaking to their own carelessness and inexperience. What I shall relate occurred between a gentleman and myself. One day, when Barbel fishing in the Trent, and having very good sport with a five dram line (a shade finer than the one recommended above for float fishing), a gentleman came up to me and made the following remarks :"Upon my word, fisherman, you have had first-rate sport; well, I never saw the like, why there you have got another: they are biting every swim; that fish must be four pounds; well done! I never saw Barbel bite better; and what beautiful tackle you are fishing with; it appears to me you understand how to use it too. Your line is really very fine, but I suppose you think it none too fine. I should like to buy a line like this." "Well, Sir," I said, "I have got one in my pocket-book made from the same silk, and the same size as the one I am 
fishing with; here it is, and the price is two shillings." "Yes," replied the gent, "it appears to be something like the one you are fishing with; I will buy it, and the next time I come fishing I will try it; here is your money, and I bid you good day." In about a week after I went to fish in the same place, and just before I got there I met the gentleman to whom I had sold the line, who saluted me in the following style: "Halloo, fisherman, that line I had of you was good for nothing, it was as rotten as a bit of cotton. I went the other day and hooked four or five good fish, and each and all of them broke the line, and ran away with float and tackle as well. Now mark, if you don't find me another line, or return to me the two shillings, which I gave you, I shall consider that you have picked my pocket." I replied, "No, Sir, I shall not return your money, neither shall I find you another line, until I see which is to blame, you or the line. Go and fetch your fishing tackle and come along with me, and let me see how you broke this line." He did so, and we went on together. "Now, fisherman," he said, "you take the rod, and I warrant you will be convinced in less than five minutes that the line is the worst you ever fished with." I did so, and the first fish I hooked was three pounds; I killed him, making the remark, "that has not broke it." I hooked another and killed him, and made the same remark, and so on with five or six, making the same observation as to the line not breaking after the capture of each. "Now, Sir," I said, "it is your turn. Take the rod and let me see how the fish break it in your hands." He did so, and hooked a fish the first swim, which would certainly have broken uhe line in a moment had I not snatched his hand from the reel, saying, "I shall not allow that, you must let the line go when he wants to run, or else something is sure break. I find you have been trying your strength with the fish; you fancied you could pull quite as hard as the fish, and of course smash went the line; then you come to me and say it was a bad, rotten line, and call me a pickpocket. He went on angling and killed four or five good fish as well as any man could, without in the least strain- 
ing his tackle or line. "Well, fisherman," he at last said, instead of my convincing you that the line was a bad one, you have proved it be a very good one, just the reverse of what I expected. I find now that I was to blame and not the line. I think I could kill the largest fish in the river with the line, which, an hour ago, I believed to be the worst I had ever fished with. What a blunder I have made, and how ridiculous I must have appeared in your eyes, you knowing better all the time. Weil, fisherman, the lesson you taught me this morning I shall not forget; and here is a crown for you, it will make a little amends for the rough remarks I made when we met." "Well, Sir," I observed, "I feel pleased you are satisfied; and you will now see that no Angler need allow a fish, when once hooked, to break his tackle, be it ever so fine. I have killed thousands of Barbel in my time, and never knew what it was to break a line with a fish." I hope all my pupils and friends will take a lesson from this, and never have to say that a fish broke their tackle.

The Float for Barbel fishing should be a cork one, long and thin, as this make of float passes through the water quicker and better than one made of the bung shape. It is better without paint; the cork made smooth, and varnished, is all that is required.

The Tackle for Corking should be one yard of fine gut, care being taken that it is not too stout, for when you get fast, it will break your line and you will lose your float and tackle as well. Let the bottom gut, especially, be fine and round. Place your bottom shot one foot from the hook; five or six BB shot is sufficient; if you require more weight put corking weights on your line, to fall on the top of the tackle. Let your shot be the thickest together near the top of the tackle, and taper them down to the bottom. Your hook should be a No. 3, tafted on with a bit of silk line, and noosed to your gut.

The Tackee for Plumbira should be made of two stout guts, which will be sufficient; tro shots in the middle, and a No. 2 hook tafted on the same as the above. 


\section{THE BEST BAITS FOR BARBEL, AND THE BEST}

\section{METHOD OF USING THEM.}

The CADBAIT is very tender and will not stand much knocking about, and when the fish are in rapid streams, you can only use it with the plumb. Let your hook be a No. 6, lapped on with white silk-not tafted. Put two or three baits carefully on so that they will form a little bunch. It would be useless throwing any of these baits in for the purpose of getting the fish together, the stream being strong, and the baits so light, there would be no calculating to what distance they would swim before they got to the bottom.

Worms for bait should be carefully selected and put into moss, well washed, shaking them up two or three times a day. In two or three days they will become tough, and of a bright red. The worms for ground baiting, or for throwing in whilst fishing, are best not scoured. I have always found those fresh from the ground to be the best for this purpose. You may fish with worm either with the plumb or float, but I should recommend you to fish with the float when you can, and with the plumb only when you are obliged.

Cheese made from old milk is the best for Barbel fishing, white and tough without salt. You must cut it up into square bits about the size of small dice. You must not use a float when fishing with cheese, except where the water is still and your bait can lie on the bottom. It would prove a bad spec were you to fish with the float in a stream with cheese. The plumb is the best to use for cheese fishing.

Greaves or Scratching require first to be broken with a hammer; then put into a saucepan with sufficient water to cover them, allowing them to boil for twenty minutes, frequently stirring to keep them from burning. Afterwards put the pan in a cool place until the scratching is perfectly cold and stiff, when it is fit for use: this is the best method of preparing greaves. You may use this bait either with plumb or float, 
but in either case the stream must be very slow, so that the bait can lie on the bottom.

Ground BarT with worms for Barbel, a place which you fancy, and in which you may think a stock of fish lie. Use for this purpose fifteen hundred dew worms, but do not mix them with anything as some Anglers recommend. Believe me, this is a vulgar error, and heed it not-it is mere "bosh." Do not cut the worms up, but throw them in whole: if you cut them into small pieces they will be eaten up by all sorts of small fry, and not by the fish you bait for. Never bait a place at night to fish the next morning. If you bait at night you should not fish before the next night. If you wish to fish in the morning bait on the previous morning. I always allow twenty hours to elapse after ground baiting before I commence to fish, and this, I have found by experience, to be about the right time. If you ground bait with cheese cut it into small squares about the size of dice; a three half-pint pot will be sufficient to bait any place where the fish are numerous. Throw the cheese in without any other mixture, and do not fish before THIRTY hours after. I do not approve of baiting with scratching, although I know many Anglers use it as a ground bait, but I am convinced that if they would merely throw in a bit now and then when fishing, and keep moving from place to place, they would kill more fish than if they had ground baited. There is no other bait that you can catch three or four Barbel with so quickly as scratching, but although the fish are very fond of it, they can eat but little, and ground baiting with greaves sicken them for a long time. Some Anglers use different sorts of scents and colouring for their baits to attract the fish. I know an Angler who says that he has got a scent to flavour his bait that will draw the fish towards it from a great distance, just as a loadstone would attract a needle, and that if a fish comes anywhere near this perfumed bait, he cannot refrain from taking it. I certainly consider this Angler very selfish in keeping so valuable a secret to himself, and not revealing it to the world for the benefit of the angling fraternity. I am sorry to say I do not know any of these attrac- 
tive scents, unless the following may be considered one :-Take two pounds of judgment, four pounds of patience, and six pounds of practical knowledge; mix the whole well together, and I think you will find it to be a valuable recipe for taking any of the twelve fish treated of in this book.

\section{THE ART OF ANGLING FOR BARBEL.}

The best state of the water is when it is clear and low. The best wind for Barbel fishing with the float is that which blows behind you, no matter from what quarter it comes, North, East, South, or West, so long as it blows off the bank from which you are fishing, and slightly up the river. Some Anglers contend that the fish will not bite when the wind is in the East but I have satisfied myself by experience that this is "bosh." I know several swims in which it would be impossible to fish with the float for Barbel with any other than an easterly wind. I am speaking of fishing from the bank. Of course if you fish from a boat or punt the directiou of the wind does not matter, as you can shift your position; but you must remember that it is useless attempting to Barbel fish with the float when the wind is blowing in your face or down the river; the latter especially will beat you, as the stream near the top is then impelled much faster than the current at the bottom, so that your float is driven forward, while your tackle and bait is dragging behind, which is the reverse of the proper style. Your bait should always be in advance of your float: never allow your bait to trail on the bottom, but just to miss it, nor your line to swim before your float. When the wind is blowing right for you, by allowing the line to go rather tight, you keep it behind the float, and the float will then point up the stream, while the tackle will go in advance of it. This is what I call putting the bait against the noses of the fish. When your bait is swimming in this style, the fish can take it without much trouble; all that he has got to do is to open his mouth and let it go in. But when your float is swimming first, and your bait dragging on the bottom, your shot 
and tackle come against the nose of the fish, and if he should happen to see the bait, he has to turn round and swim after it before he can take it, which he seldom will do unless he is very hungry. I remember a keeper on the Trent sending for me to catch some Barbel, his water being overstocked with this description of fish. I went and found first-rate Barbel fishing, and the fish a good size. About the middle of the day, when I was eatching them very rapidly, the keeper came round and was much pleased with the sport. He said, "you appear to catch them so easily that I think I could catch one: will you letme have atry ?" "Of course I will," I said, and I put a fresh bait on for him. Now this keeper had at least twenty swims and did not get a single bite. He was fishing with the same kind of bait, in the same swim, and with the same depth as I was, but not a nibble did he get. He gave it up and went away, saying "It is no go, fisherman ; I can't catch one; they dont know me." Well, the first swim I had after he was gone I got another, and many more before I had done. Now what was the reason that the keeper did not get a bite? I knew, but did not feel disposed to tell him then. The simple eause was that he allowed the line to swim before the float and the tackle, and the bait dragged behind as I havealready described; and, reader, if you do not remember to avoid this, you will meet with no better success than he did. If but one little thing is done wrong, all is not right. In nineteen cases out of twenty, when the Angler returns home with his basket empty and his mouth full of all sorts of absurd excuses, his want of success has been entirely owing to some error on his own part-some fault has been committed. He has perhaps thrown too much ground bait in at first, which is a serious mistake; or he may hare thrown his ground bait too high up the stream, and it has sunk before he thought it would, in which case the fish would be all above him; or he may have thrown it too far down, and it has gone out of his reach. To obviate this last mistake, I would recommend the Barbel fisher to have a swim occasionally of twenty or thirty yards. When he has discovered his mistake, he can remedy it by throwing his ground bait a little higher up 
the stream, so as to draw the fish nearer to him. When the water is very clear I would not advise you to attempt to get the fish too close to you, but keep them at a distance, say ten or fifteen yards ; they will bite better and longer by so doing. It will be impossible for me to explain how or where to throw your worms or any ground bait in, as the water being of a different depth in different places, the ground bait requires to be thrown differently in; but I will describe a good plan. When you have found a Barbel swim get the depth by allowing the bait on your tackle just to miss the bottom; select that part of the swim which bas the levellest bottom-free from large stones, weeds, or anything foul. If you are going to fish with dew worms, cut about twenty, each worm into four bits, but not more, as if the pieces are too small they will be eaten up by little fish before they get to the bottom, and of course will have no effect. Throw them in, making a calculation for the stream and the depth of water, and watch the course of the stream, for depend upon it wherever your worms go there will the fish go also, and unless your bait follows in the same direction you will get no sport. If the first few worms do not take effect in ten minutes, throw in as many more in another direction, either higher up, lower down, further or closer in, as you may conceive to be most advisable. Continue this plan for an hour, trying every dodge you can think of, but if you find that you are still unsuccessful, as a last resource, if you have plenty of worms, cut up a hundred or two and pitch them in. If, after fishing for twenty minutes longer, this has no effect, abandon the place and seek another. The reason I do not recommend throwing much ground bait in at first is, that you may have selected a swim in which there might only be five or six Barbel, and if you have cut up and thrown in two hundred dew worms, the moment they get to the bottom the fish will devour them up as a lot of chickens would a handful of barley thrown to them, and the consequence is that you cannot get a bite, because you have given the fish more worms than they can eat, and being satiated they will not look at your well-scoured bait. If you could see the bottom and the 
number of fish you were going to augle for, you would know what to do, but as you cannot do this you would be acting quite right by adopting the plan I have laid down, commencing by throwing in a few, and finishing by pitching in as many as you like. As the Angler cannot see beyond a foot or two of the surface of the water, he cannot tell what is going on underneath. I have often thought it would be a great thing for Anglers if some glass or instrument were invented to penetrate through the deep water so that one might see the fish and all there was between the surface and the bottom; we could then make our arrangements for fishing with considerable ease. And who says such a discovery is impossible? Look at the wonderful inventions which are daily and hourly made, inventions which a century ago were never dreamt of. We live in an enlightened agean age in which so many discoveries and improvements are made in the arts and sciences, that one cannot help thinking that such an instrument as I have described could be easily invented. I am persuaded that if some of our great scientific opticians gave their attention to the matter, a glass could be constructed with which one could discern everything from the surface to the bottom, at least where the water was clear and not more than ten or twelve feet deep. Such a discovery would be a great boon to the Angling fraternity.

I will show you how I have several times been cheated for the want of an instrument of the above description, how I found out the cheat, and the reason why I recommend a large quantity of ground-bait being used as a last resource. I commenced fishing a Barbel swim, where I thought there would be plenty of good fish, with the wind and water to my mind, and a thousand worms to start with. I felt confident I should have good sport in a short time, which I had, as you will see. I started by throwing in twenty worms, just as I have recommended, and followed this up by giving the fish five or six such lots in the course of an hour. I fished in a style that I thought nothing could beat-the float going down the stream as steady as if there was no line attached to it, and the tackle and bait going 
in the right form; in fact, I was fishing as well as I could wish. A whole hour passed away without a single nibble. In vain I perplexed my brain to discover from what my want of success arose, and I was actually beginning to become disgusted with myself and everything around me, when as I was throwing from the reel, I happened by accident to throw five or six yards higher up the stream than I had intended, and which I had not done before. The float did not cock, and I fancied the tackle lodged on something coming down the stream. I was proceeding to draw it out to throw in again, when, behold! T. found a Chub of a pound weight had caught hold of the bait, and kept it from sinking. I got him out, and pul another bait on, and went up five or six yards higher, and threw again. The float lay flat on the water, just the same as before. I struck, and caught a Roach, half-a-pound. I threw again, and caught a large Dace in the same way. I began now to see what was the matter. I said to myself, "You rascals, I will give you such a quilting as you have never had before." I took off my Barbel float and tackle, and put on a quill float and Dace tackle, with a No. 8 hook, baited with the tail of a female lob. The water was 12 feet deep, but I arranged the float so as to fish about the middle. Well, most astonishingiy, I had a bite, either of Roach, Dace, Chub, or Perch, every swim, without having to throw in any more worms. In about an hour I had silenced all their guns, and caused those that were left to retreat. When I found the little fellows were all gone, I went to my worm bag, took out about a hundred, cut them up, and threw them in the same place that I had done before. I then again put on my Barbel float and tackle, and fished in the same style as I did when I first commenced. The first two swims I had not a touch, the next three I hooked a Barbel each swim; it then appeared to be all over, for I could not get a bite, but as a last resource I cut about two hundred worms in bits, thinking to myself that if they did not take effect I would leave, and seek another place. But they did take. effect, for the fish came on to bite in good earnest, and I believe. witbin the last hour that I fished I caught nineteen good Barbel, 
which I found to be as much as I could carry, and I went home quite satisfied with my three hours' fishing. Some Barbel fishers who may read this may say that if I had given them two hundred worms at first, and followed it up in twenty minutes with as many more, I would have killed all my fish in the first hour, and saved a deal of trouble besides, which I readily admit, but I did not know that there had been about two or thiee hundred Roach, Dace, and Chub swimming five or six feet from the surface, and eating up the worms as I threw them in, not allowing a bit to go to the bottom. Had I known this, by throwing in a good dose at first, and following it up with another, I should have satisfied the small fry, and the Barbel would have come on to bite thick and fast. But, as I said before, it is impossible to know what is going on under the water. If we could see everything from the surface to the bottom, then angling would become very simple; but as we cannot see what we would wish to see, we must try and do the best we can. And as such swims as this I have described are few and far between, $I$ would recommend the Barbel fisher to adopt the plan I have already mentioned, and $I$ am satisfied he will not be doing wrong if he will abide by it, namely, by throwing in a few worms when commencing, and finishing by casting in as many as he likes. Some Barbel fishers have a very bad system of ground baiting the place while fishing. They get the fish on the bite, and every fish they kill, in goes a lot more ground bait. "My word," they say, and I have heard them say it, "they are biting first-rate this morning; give them some more worms-let us keep them together-we have plenty of worms, don't spare them-there is any quantity of fish here, and large ones too-give them plenty, I am sure they can do with it." And this game they repeat every fish they catch. O, you Neddies! don't you know what you are doing? Does not common sense teach you that each fish can only eat a certain quantity, and by throwing the worms in to them as you do, you satisfy five fish for the day for every one you kill. You spoil your sport by the very means you took to preserve it; for in an hour you have perhaps filled the stomach 
of every fish in the place, and then you feel disappointed because they will not bite, as you felt confident of a first-rate day's sport when you commenced so successfully. The fish have gone off biting, but there are still plenty in the place which you must have caught had you ground baited judiciously. Years ago I used to do this sort of thing myself, but experience has taught me better, and I now feel convinced the system is bad. I will give you my style of ground baiting whilst fishing. Supposing the place has been baited the day before with fifteen hundred worms (I allow twenty hours to pass after ground baiting, before I commence fishing), I expect a good stock of fish to be collected together, say fifty Barbel, which $I$ have often found to be the case, after a baiting of this sort. There is one point in which I am very particular, that is in calculating, when I throw in the first few worms, what distance they will swim before they get to the bottom, so that I may catch the fish ten or fifteen yards below me-no nearer, for as I told you before, they will bite lunger and better by keeping them at a distance. I throw the first few worms in one place, so as to keep the fish within as small a space as possible. I never spread them about more than I can help, if I did it is evident the fish would be feeding in all directions. I should never know what part of the swim was the best to fish for them; besides, having got the proper depth for one particular part of the swim, I can fish no other portion of the swim without altering my float to suit the various depths; so to save time and trouble and to ensure sport, I throw the first few worms in that part of the swim I have selected and got the depth of. By thus doing I keep the fish in one channel. I am sure many a baiting has been ruined and the sport spoiled for the day because this point has not been properly attended to. Well, I have supposed fifty Barbel to be in the place selected. I commence by giving them twenty dew worms, each cut into four bits. Now what effect will twenty dew worms when cut into eighty pieces have upon fifty hungry Barbel? I should say a general scramble takes place among the fish, each endeavouring to get more than his neighbour: some have got two or three 
bits and others have not tasted. None have had a chance of filling their bellies, and those that have tasted are very keen and eager for more. The next lot $I$ throw in is a well-scoured female lob on my hook, which is picked up the moment it gets to the bottom. He that has got it will find it rather difficult of digestion, and not so palatable as he at first might fancy it would be. Well, I have got them on the bite every swim, and I have caught five or six fish in as many swims; but it would not be judicious to go on at this rate, as I have createl some alarm amongst those that are left. The rushing and dashing about in all directions of some of their relatives have bamboozled and frightened them, and made them somewhat restless, so I give them a few more worms, lay my rod on the bank and light a pipe or cigar, leaving them unmolested for two or three minutes that they may recover from their surprise and consternation. Then I go at it again and kill four or five more fish before giving them any more worms, and when $I$ do so $I$ only let them have a few as before. This is a sure and certain game; but even with this treatment $I$ have generally found them to go off biting after fishing for three or four hours, and, observe, I always expect this, and when I come to have five or six swims without a bite, I know they have gone off biting-not because they have been satiated with the worms which I have been throwing in, but because they have been continually disturbed and rendered shy by thehooking and killing of their neighbours. I know they will come on again in an hour or two, so I leave the place without throwing in another worm. Some Barbel fishers at this stage of the game recommend giving the fish two or three hundred worms, and leave them. It is in my opinion a very bad plan. The fish recover, and eat of the worms till they are satisfied while the Anglers are away. They have had enough for that day, and if you think of catching them you must call to-morrow. The Barbel fisher when he returns again finds it no go, so he laps up his tackle and bolts home, believing that he did not leave a fish in the place. I like to be fishing while the fish are eating the worms that I have thrown in, and then there can be no mistake. 
You cannot help catching fish if you are angling at the same time that the fish are feeding on the worms you have thrown in. Some people may perhaps say, if the fish should return while we are away and find nothing to eat, they will leave the place altogether and seek food elsewhere. This is a mistake. I have proved hundreds of times that they will and do stop. I consider the baiting I have described has been quite sufficient to keep them about the place for one day at least, if not for two or three. If you wish to fish the place a second or third day throw in five or six hundred whole dew worms at night after you have done fishing. I have sometimes found the fish bite better on a second or third day than on the first, but not after. The first day has invariably been the best. If the wind blows wrong and you have not a chance of fishing a place you have baited on the first day, do not give it up. The fish are there and will bite as soon as you can angle for them in the right style. Come again on the second day, and if the wind is favourable there is nothing to prevent your having good sport.

When the water is very clear, what I call gin-fine water, then Barbel fishing is very difficult, more so than any other time, as the fish can see the deception you are using to trap him, and is very cautious and suspicious You should then fish with the finest tackle you can get, and let your bottom shot be eighteen inches from the hook. The fish can also see you or your rod, or anything shadowing over the water, when you little think he can, and if he does is off in a moment like a shot. This is the time that Barbel require a deal of "foxing," and I am certain the man that can catch them well when the water is clear and the sun bright, must understand something of Barbel fishing, but to give an idea of the best mode of dodging and licking him in this state of the water, I will relate what occurred on one occasion with a party of gentlemen whom I accompanied to a Barbel swim on the Trent. Having occasion to go to the Thames on a fishing excursion, my friends engaged other fishermen to fill my place while I was away. The water being very fine and low nearly all the time, Barbel fishing was very difficult. 
Several places being baited and fished without success, the gentlemen and fishermen as well arrived at the conclusion that there would be no more Barbel caught until there was some rain, and a change in the water, for the water was too clear. This was the general complaint made to me on my return by the gentlemen, but- $\mathrm{I}$ told them I did not believe in the water being too clear for Barbel fishing, and that they required only to use a little more foxing and to fish in a different style. "Well," says one of the gentlemen, "will you go and bait me such a place; although it has been baited and fished several times of late without much success, I have no objection to give it another trial if you think there is a chance of nailing the fish." I knew the swim selected to be a very good one for Barbel fishing, and I accordingly went with fifteen hundred worms to bait the place. The water was as clear as ever it was, and the day bright and hot, which was another difficulty. I went cautiously to the water-side and threw the baiting in the usual style, mixing with. nothing, and came away leaving the result till the morrow. I had not got a mile from the place when I met another gentleman, a friend of mine, who is passionately fond of Barbel fishing. $\mathrm{He}$ asked me what I was doing there, and said he thought I was in London. I answered, "but you see I am not. I returned two days ago, and have just been to bait a place for a party of gentlemen." "Then, let me tell you," he said, "you will do no good; the place has been baited and fished three or four times since you last fished it, by some of the best Barbel fishers in the town. I have also had a try at it, and fished it as well as any. man could and I caught no fish :, the water is too clear for Barbel fishing, that's certain; and, mark me, you will get such a licking as you have not had lately." "Well, I replied, time will tell; the place has always turned out a good lot of fish when I have fished it ; in fact, I have never known it fail, and if this should be a failure it will be the first. I suppose you will be fishing about this neighbourhood to-morrow, if so, you will be able to to see what sort of a licking I do get: so I bid you good morning." On the following morning we went down to the place I had 
baited - two gentlemen and myself. The sky was cloudless, and the sun very hot, with scarcely a breath of wind, which made things look rather awkward, and made me feel the chaff and sarcasm of the two gentlemen rather sharply. I certainly never saw a worse morning for Barbel fishing in my life, there was not a single thing in our favour; but still I had some confidence on account of the arrangements $I$ had made, which $I$ felt sure would answer the purpose if we went quietly to work. The gentlemen were down in the mouth, and the little confidence they had was greatly shaken when I told them what the person who met me coming from ground baiting had related, for they knew that he was a first-rate Barbel fisher; but I told them to cheer up, for patience and perseverance might work wonders. When we had got to the spot, I said to the one, "stand you there," and to the other, "stand you here," stir for nothing, and be as still as death; whatever you want doing I will do it; all I require of you is to stand still and kill the fish. "Now you shall see that this place was fished in a different style to what is usually done. T'he water was about nine feet deep and as clear as glass. The swim was not quick, and in water of this description I generally go up five or six yards from where I stand to fish to throw the worms, and catch the fish eight or ten yards below me, so that the worms swim fourteen or fifteen yards before they get to the bottom; but in this case I threw the worms two yards below where we were standing, so that the fish would be nearly twenty yards from us. Well, the first swim both got hold together and killed two Barbel; the next swim they killed two more; then one killed and the other missed. When we had caught nine, one gent s.id, "this is firstrate sport-better than we expected; if they take the bait at this rate for three or four hours we shall have a load, that's certain. I shall go and stand eight or ten yards below; I don't fancy such a long swim, you see we cannot get a bite until the float is twenty yards from us." "No," I said, "you must not stir a yard, the fish are biting every swim, what more do you want? You are doing well, so be satisfied, and stand your 
ground. If you were to go where you want it would be all over with you; the only chance you hare is to eatch them a long way off." I now threw in a few more worms, two yards lower down than the first lot, which made the fish bite at least twenty-five yards off. This was a great distance to hit a fish, but they were hit to perfection, for a bite was seldom missed, or a fish lost. When we had fished for three hours they went off biting, and we left the place and had a bite ourselves. We returned in about a couple of hours and found them as keen and eager for the bait as when we first commenced. I must tell you I never gave them a worm while they were biting, but when I saw two or three swims without a bite, I then threw in a few. By taking this plan I kept the fish hungry all the time. In about five hours and a half we caught one hundred and thirteen pounds of Barbel without stirring a yard from the standing we first took up, and every fish was hooked from twenty to five and twenty yards off. On our return to the village I sent for my friend who had promised me such a licking, and you may fancy his surprise on beholding three baskets full of Barbel. "Now," I said, "you see what sort of a licking we have got-not quite so bad as you expected, and I hope the next time you go Barbel fishing you may get licked no worse. After this I think you will agree with me that the water cannot be too clear for Barbel fishing."

When there is a rise in the water, say of one yard, and it is very thick, you must remember it is useless fishing with the float, as on account of the water being thick the fish are unable to see the bait when swimming down the stream. The plumb is then your only chance, as in fishing with it the bait lies upon the bottom, and when it does Barbel will be sure to find it, no matter how thick the water, or how dark the day. The Londoners fish for Barbel with the ledger, a perforated bullet, which rolls on the bottom and keeps the bait moving for a time; when it settles they wind and throw again, expecting to get a bite, while the bullet is moving. If they tried this style of fishing when the water is thick they would find it a failure. Some writers 
on Angling recommend the ledger as the best mode of Barbel fishing, but in my opinion it is the very worst, there is nothing in it. As I said before, it is too "slow," and will not do for the Barbel fishers of the present day. In fact, if you see a man plumbing, ledger fishing, or whatever else you call it, when there is a chance to fish with the float, I set him down as a "duffer," and a lazy fisherman. For my own part I would prefer a quiet day at home, and a tune on the "old banjo," to fishing for Barbel with the plumb. When the water is high and thick you must not fish for him in the deeps. You will find him in the shallows, of about four or five feet of water, with a gravelly bottom, just above a deep water and a brisk stream. These are the likeliest places to find Barbel when the water has risen. Suppose you hare not fished the place before, and do not know the exact depth, but think it a likely place, the first thing you must do is to ascertain the proper depth either with the plummet, or by putting on your Barbel float and tackle, which I think the better plan, because you will be able to know what sort of a bottom you are going to fish on, whether it be level or whether there be any thing foul about it. The water being thick, it might be full of weeds without your being able to see them, so by putting your float and tackle on you will soon discover if the bottom is all right. The reason I recommend you to get the depth first is, because I suppose you intend to throw in some sort of ground bait to entice the fish to take your bait on the hook. Well, if you do not know how deep the water is, where is your calculation? How shall you ascertain one of the greatest points in angling, that is, to know to a nicety where your ground bait has gone to? It is impossible for any one to catch fish well unless he has some idea where his ground bait will rest. If he has not, it will be great good luck if he kills a fish. You might as well strew your ground bait on the bank as in the water if you have no idea where it has gone to. Well, after you have got the depth of the water, take fifty dew worms and cut them up, (you need not be particular about a few worms when the water is thick, as they won't be so easily found), and throw them in 
three or four yards above you, and six or seven out in the water, observing the course the stream takes; then cast your plumb a little across and down the stream to the rery spot you think the ground bait has rested. If you do not get a bite in five minutes wind up and make a shorter or longer throw, whichever you deem best, but always in a line with the course the worms took. When you get a bite you will know where to throw to get another. When you have caught four or five fish cast in twenty or thirty more worms, but be careful and throw them in the same place as you did the first lot, then there is nothing to prevent you having a good day's sport.

\section{CHEESE FISHING FOR BARBEL.}

I will suppose you have baited a place with the dose I have recommended, and allowed thirty hours to pass before fishing. The water must be deep and the stream slow for cheese fishing, because if you were to throw cheese into a sharp'stream with a gravelly bottom, it would swim a long way before it got to the bottom, and when it did get there it would roll to a great distance, in fact, it would never stop untii itlodged against some obstruction in the water, and not only that, but Barbel do not bite at cheese in streams. The best time to catch him with this bait is when he leaves the streams about the beginning of August, and takes to deep and still water. If the water runs deep at the side you may commence fishing with the tight float. It is done in this style: take your cork float, and tackle recommended for cheese fishing, and put it about two feet deeper than the water, so that your bait and first two or three shot may lie on the bottom. Cast it down the stream so that your tackle and bait may sink itself, and allow your bait to lie straight down the stream; hold it quite still, and at the same time be careful how you move about on the bank, for the least shake will drive the fish away when fishing so close to the side. But before you commence, throw in about twenty bits of cheese, and find them before you throw any more. I mean, catch two or three fish before you cast in 
another supply. I am always particular on this point, trying every dodge I can think of to find where the first bit of stuff has gone, because if I were to give them a lot nore cheese without catching a fish they would eat it up, and I would still be in the same fix. The fish would be filling their bellies while Ishould have been filling my basket. I, therefore, determine to find them out after they have got the first dose. You must remember what you are fishing with now, for a very few bits of cheese will satisfy a Barbel, so that if you don't catch him after throwing in a little you won't catch him at all. Plumbing will answer the purpose better for cheese fishing, as you can fish in deep water, and catch fish at a greater distance than you can with the tight float, which is of course much better. As I have already explained the style of plumbing with the worm, you will understand how to plumb with cheese.

If you bait a place with scratching, one pound and a half, prepared as I have already shown you, will be sufficient, but I am sure it would be better not toground bait at all - so experience has taught me. Take your bit of stuff and shift from place to place - catching one or two here, and three or four there-fishing with a quill float if you can, if not use a light cork one, and No. 6 hook. Tight corking is used the same way and in the same places as I have recommended for cheese fishing, throwing in merely a very small bit of scratching now and then while fishing, by which method I am convinced you will take more fish than by ground baiting.

Now, I think, if you will pay proper attention to this lesson on Barbel fishing, there is no fear of your ever getting " licked." 


\section{THE $\mathrm{CH}$ U B.}

This is a clumsy-looking, thick-headed rascal, rather coarse, and not much thought of as an edible, but he affords first-rate sport, and if you fish for him with a light rod and fine line, it is ten to one if you can manage to kill him, especially if there is a bush or old tree in the water, or a shelving bank near, under which he will bolt the moment he feels he is hooked, and if he does get into any of these places, he will soon play the deuce either with your rod or tackle, or both, and this is more than can be said of some of the finer fish. He is a determined and resolute fellow to deal with, and if he only gets a chance, and you fish for him with a fine rod and tackle, he will make you pay dear for your sport.

Chub spawn about the middle of May, but I have on several occasions seen them on the spawn as early as the first of that month, but never sooner. Barbel and Chub generally come on together about the middle of May, and deposit their spawn in the same description of places-a shallow gravelly bottom under the weeds. Chub bite sooner after spawning than any other fish I know, particularly at such baits as the minnow and locust, which he takes greedily in a day or two after spawning, and he seems to bite freer and with less fear at this period than at any other time. You will find the Chub for the first three or four weeks after spawning in the sharpest and shallowest streams, to which places he resorts for the purpose of cleansing himself. He makes his next 
move about the latter end of June or beginning of July, when he makes for deep Barbel swims, orgoesunderweirs, bushes, and trees overhanging the water. These are favourite places with him during the summer months. Towards the latter end of October or the beginning of November he seeks shallow water-a gentle swim with a gravelly bottom, by the side of willow beds, under old trees sunk in the water, or anything that will afford him cover and a home for the winter months. You never find Chub on a sandy bottom. I do not remember ever killing a Chub on a sandy bottom. He prefers at all times of the year a rough gravelly bottom.

The Chub may be found in most rivers and small streams in England, but perhaps the Trent is the best for the number and size of this fish. I was surprised when in London, on the occasion of paying a piscatory visit to the Thames, to find that in all places where stuffed fish were to be seen, that, although there were beautiful large specimens of every other fish, I saw no Chub but of a very small size, averaging perhaps about two or three pounds weight, the largest not exceeding four pounds. From this I infer that there are no large Chub either in the Thames or any other streams in the vicinity of London. Now, we think nothing of a Chub four pounds weight in the Trent. I killed one myself not long ago which weighed six pounds and a quarter, and I once killed one that was only two ounces under seven pounds. This was the largest I ever saw, but five and six pounders are very common in the Trent. I have several London friends who come down occasionally for a few days Chub or other fishing, and they all acknowledge that the Trent Chub are the largest they have ever seen.

The best season of the year for Chub fishing is from November till the end of March, but I once made an extraordinary eatch about the 14th or 15th of April. The morning was very misty, which is the best state of the weather in which to fish for Chub at all times. The Chub is a winter fish, for he is in the best condition in the coldest months, and bites freer in the winter than any other fish. It matters not how cold the weather may 
be, he will bite if the water be clear and the day cloudy or misty. In fact, it is no use fishing for Chub when the water is thick; it must be clear else you have not the shadow of a chance. I am not particularly fond of Chub fishing in hard frosty weather, not because I cannot stand the cold as well as any other man, for I prefer cold to hot weather, but because every fish I kill I must lay down the rod and suck the ice out of the rings before I can make another start, which is a very great bore. Talking of the cold weather reminds me of a circumstance which occurred in January, 1856. It was a cold misty morning, the water being clear and just to my mind. I felt confident of a good day's sport. As I was on my way to an excellent Chub water, and passing through a village near to the place, I overtook two men, one of them a barn-door savage, who saluted me as follows:- "Hollo, mate! what! going a fishing on a day like this? Why, you deserve three months in the House of Correction-that you do. The idea of fishing! I should not like to wait for my dinner till you caught one." "Well," I said, "if you had to wait for dinner till I caught one, what then?" "Why," he replied, "it is the greatest certainty in the world I should have to miss a meal for once. Go on with you, a fool at one end and a worm at the other." I felt somewhat annoyed, but I asked him if he lived anywhere near about. "O yes," rejoined he, "this is my house : shall you call and leave us a fry? Don't you wish I may get it?" "I will promise you a call," I said, as I went on my way, "when I return, but leaving you a fry is another matter; they want eatching first." Well, greaves or scratching was the bait I was going to fish with. From the first place I fished I took twelve, averaging three pounds each; at the next place I killed seven, and out of the third and last place I got three, in all twenty-two fish, making a total weight of sixty-five pounds. They were all caught within two hours and a half. I had three miles to walk to the station, and with this weight of fish to carry I had no easy job I can tell you. On my way back I gave straw-yard Johnny a call. I set my fish down at his door and knocked. "Is the master at home," I said, when it 
was opened." " "Yes, he answered, I am bere," and he came out." Well, fancy the old fellow's surprise on seeing the fish I had caught: he could scarcely believe his own eyes. "Well," he said, "if any one had told me that a man could go on a day like this and catch such a lot of fish I would'nt have believed him." "But you are obliged to believe this," I said, for there they are before your eyes. You made all sorts of game of me this morning, and shouted fool at one end and worm at the other. Now, who is the fool? You little thought when you were chaffing me for going to fish on such a day, that the day was in my favour, and most suitable for angling for this kind of fish. No, you had no idea of that, and in your ignorance you made game of me. I should think this lesson will teach you to mind your own business for the future, and let a fisherman pass without insulting him.

The Beste Batts for Chub Fishing.-You must remember no two baits that I shall mention will eatch Chub all the year round, but $I$ shall state what are the best at the different periods throughout the season. Immediately after spawning the best baits that can be used are the minnow, locust, and artificial flies. The first two or three weeks after spawning I have seen Chub bite every swim at the live minnow. To fish in the proper style with this bait, you will require a very fine silk line, a quill float that will carry seven or eight BB shot, a fine tackle two feet long, and a single hook, No.4. Let your bottom shot be about nine inches from the hook; hook the minnow by the mouth, fish two or three inches from the bottom, and take a swim of fifteen or twenty yards down the stream. The water must be clear and low, and if you fish the places I have recommended at the season that $I$ have indicated, you are sure to catch Chub. It is not worth while Chub fishing with the minnow after the first week in June. I have also seen Chub take the locust nearly every swim. The same line and float will do for the locust, but the bottom tackle must be different. Instead of a single hook you will have to use a double one, and place a small swivel nine inches from the hook, and noose the 
bottom gut to it. But before you do this, take a fine baiting needle and put it in under the head of the bait, and bring it out at the tail, drawing the shank inside the bait. See that the noose is sufficiently large to allow the bait to go through, then put the noose through the swivel, and the bait through the noose and draw it up. Fish with the bait three or four inches from the bottom. I have seen Chub take the artificial fly very freely in a sharp stream, about a foot deep, on a gravelly bottom, and it is first-rate sport when you hook two or three at one cast, as I have often done. When they are lying thick together scouring themselves, they will rise to almost any sort of fly. The red hackle and red palmer flies ribbed with gold, on No. 9 hook, I have found to be good killers at this season. You may also catch Chub all through the summer, more or less, with the artificial fly, but it is all over for the year with the first two baits recommended after the first three weeks have passed. From this time till October, the dew worm or cockspur is the best bait to fish with. During the summer and up till October you will find Chub in Barbel swims. After this time none of the above-mentioned baits are of any use. You would scarcely eatch a fish in a week with any of them. Now comes what I consider the Chub fishing season, namely, from November till March. This is the best time for Chub fishing and the best baits are greaves or scratching, and bullock's brains and pith from the back bone. These are the two best baits ever invented for Chub fishing in the winter, but I believe the last to be the best of the two-fish with the pith and throw the brains in.

Some Anglers do not fancy Chub fishing in winter, because they consider the baits disagreeable to fish with. I am not of the same opinion, for bullock's brains, when nicely cleaned and cooked, are as white as a curd, and fully as sweet to eat as sheep's brains. The renowned "Bendigo," when he goes Chub fishing, and he is no novice at this game, takes half a hatful with him, and as he is obliged to chew the brains before he throws them in. He tells me he cannot prevent a portion going down his throat, they are so sweet, so you see he fishes with one part and 
swallows the other. Two heads of brains are quite sufficient for a day's Chub fishing if the fish bite well, but you see this quantity would be of no use whatever to a Chub fisher like Bendigo.

The Best Method of Preparing Scratching.-Break the scratching small with a hammer, but be careful and not break those bits that look likely to make a bait for the hook, then put it on the fire and let it boil for twenty minutes, frequently stirring to prevent it from burning. If you find it getting stiff add more water, so that when it has boiled the given time it may be a little sloppy. Take the pan off, and allow the liquor and all to set, when it will be ready for use. This should be done over night.

How to Prepare Pith and Brains. - First take the skin off the brains and wash them in two or three waters until they become white and free from blood; then take the pith and you will find two skins on it, the outside one very thick and tough; take this one off altogether after slitting it up with a pair of scissors, but be careful not to drag the under one away with it, for if you do your baits are spoiled, and would not stick on the hook without the under skin. Slip this under skin up on one side with a pair of scissors, and lay it flat; you will then have skin on one side and none on the other. Wash it clean and let it boil with the brains one minute, when it will be ready for use.

The Rod for Chub Fishing should be twelve feet long and light; not too stiff, as your line and tackle being fine you are apt to break it when striking. The reel must be a three and a half-inch common wood one, varnished. Fill the bottom three parts full of soft cotton, and put the line above. By doing this you will have more power over the fish when hooked, and be able to fish better in every way. The line must be made of all silk, and twisted soft; one hundred yards of it should weigh about a quarter of an ounce. The float should be a turkey or swan quill one, that will carry six or eight B.B. shot. A float of this kind will be sufficiently large to fish any Chub place in the winter months. Never fish with a cork float for 
Chub. One yard of fine round gut will be sufficient tackle. The hook should be a No. 5, lapped on with white silk. Let your bottom shot be twelve inches from the hook; this will complete your tackle for bottom fishing.

\section{THE ART OF BOTTOM FISHING FOR CHUB.}

It is no use Chub fishing unless the water is clear, the wind blowing behind you, and the day cloudy or misty. A bright sunny day is very unfavourable. Chub are very shy and difficalt to get at when the sun is bright. If you happen to catch one all the rest are off in a moment; but when the water and day are favourable you may catch them to a fish, as the saying is, "you can clear the whole out." Before I go into the art of catching Chub, I will show to what perfection we have already reached in the art, but I am convinced that still greater perfection will ere long be attained, and that though some of us fancy that we can fish better than others, and are in possession of a few points which three parts of the angling fraternity are not up to, the time will come when the anglers of the present day will be thought mere "duffers," and babies in the art, for I can see boys from twelve to fourteen years of age figuring as well as some of the old veterans did twenty years back, and are promising to become first-rate artists in the gentle craft. The following anecdote will show my readers that Chub fishing is an art that requires learning, and that the Chub fishers of the present day are not altogether novices, but go to work with confidence and in a masterly style. I was not a witness to what I shall relate myself, but I can vouch for its truth, and I think a more masterly display of the art of Chub fishing was never witnessed in so young an angler. A pupil and friend of mine, who is passionately fond of Chub fishing, not for the sake of the fish, but for the sport, and who has had but five years practice, seeing the day and water all right, started for a Chub water with some scratching for bait. He had not been at the water above a minute, and was only partly tackled out, 
when two men came up to him and inquired if he had seen a pleasure boat pass. He answered that he had only just arrived and had not scen a boat of any kind. The two men were about to pass on, when my friend said, "Hold, I will go with you if you will wait a minute; there is a fish here I want to catch, and he is sure to bite the first or second swim." "How do you know, said one, have you seen him?" "No," says the confident piscator, "I have not seen him, but it is a dead certainty there is one, so here goes for him." The float did not swim a yard before it went down, and the Angler hooked a Chub two pounds weight, which one of the astonished pair landed, making the remark, "Well, I never saw a fish killed so scientifically before." My, friend now picked up his traps and was ready to go with the two men, who said, "What! not fish again after killing a fine fish like that on the first cast." "No," said the bold piscator, "There is only another fish in the place, and he would not bite now, he having seen his mate taken out, but I will catch him when I come back." Away they went together, and when they had got about a mile up the river my friend made another stand, saying, "There are two fish here, and I will throw in and catch one now, and take the other on my way back, but they are not so large as the one I have caught." Well, the first swim he caught another Chub about a pound weight, the two men being more astonished than ever. They now moved on again, and half a mile further up the Angler stopped again. "Now," said one of the two, laughing, "How many fish are there in this place: you had better tell us before you commence, and tell us also how many you are going to catch." "Well," replied my friend, "There are six fish here: I will catch three now, and the other three when I return, but they are not so large as the last." He threw a little bit of scratching in, and surprising as it may seem, he actually killed three Chub about half a pound each in as many swims. They then proceeded some distance higher up, when another halt was made, the Angler saying, as before, there are six fish here: I shall take three now and the other three on my way home. 
He landed the three in a few minutes: they were about the same weight as the last. The adroit Angler then went to an inn and had some refreshment, while the two men went in search of the lost boat. Not finding it they returned with the Angler to witness the result of his predictions. We will now follow our fisherman and the two men back, and see what occurs. My friend made it appear as if he wished to pass the first place, but the two would not allow him. One said, "are you afraid you shall get licked when you wish to pass by the place." Piscator turned round and seemed surprised, saying, "what fish did I get here when we came up." "You caught three," answered one of the men, "and said you would kill three more on the way back." "So I will," said the angler, "and here goes." In about five swims he caught three of about the same size as the first three he took out of the same place. They went to the next place. "How many fish did I kill here? asked the angler. "Three," answered the men. "Then there are three remaining, and I shall have them out in a few minutes," replied the clever Waltonian. He landed them and proceeded down to the next place, when he said, "I caught one fish here about a pound weight, and there remains another of about the same size, which I shall capture in the first or second swim. $\mathrm{He}$ hooked it in the first swim and killed it. When they came to the last place, the angler said I caught the largest fish hereabout two pounds weight-and I promised to bring out his mate when I came back. I shall do so, and won't be long about it. "I believe you," said one of the men; "It seems to me that you can catch as many as you like, and as for the size you have only to mention it and it is sure to be as you say. "Well, the first swim he caught the fish." It was landed by one of the two men and placed by the side of the first one. "Well, I never saw such a thing, they both shouted out, it is but a quarter of an inch shorter than the first." This ended what was thought by the two men a very extraordinary day's fishing, but the angler did not think so, nor do I. We know very well that if he had continued to fish the places as he should have done, and as he 
would had he been alone, he would have caught perhaps every fish at first and left none for a second trial ; but this would not answer his purpose. He likes a joke and wished to astonish the men, knowing each place well and the number and size of fish he was in the habit of taking in each. He said, "there are six fish here: I shall catch three now and the other three when I come back." But when he had caught the first three he did not try again, but led the two men to believe that though there were as many more left they would not bite then. This certainly was a grand display of the art of angling, and it would require a deal of confidence even on the part of a professional before he could undertake to perform a similar feat. Because $\mathrm{I}$ hare caught six fish in one place to-day, can I in a week after make sure of getting the same number in the same place? By no means; and I say that the man who would undertake to do anvthing like the above must possess considerable confidence and great knowledge of the art of Chub fishing.

We shall now proceed with our lesson on the art of angling for Chub. Well, you have got the tackle and other appliances that I have recommended, and let us suppose a suitable day, water and wind. Now you are going, perhaps, to fish a strange water, and have no one to show you the places where Chub are likely to be. I am satisfied that man is a good angler who can go to a water he has never seen before, and catch a good basket of fish, without being shown the best places in which to fish. This is convincing proof that he is an artistic angler. I know a few boasting fellows who catch more fish with their tongues than ever they did, or are likely to do, with the rod. They catch a fish or two in places that some other angler has found for them; but send them to a water a hundred miles from home, and they will turn out perfect "duffers." Well, take stock of the river; you perhaps see the water running down on one side in a rapid boiling stream. That is not the side for Chub fishing in winter. Do you perceive those willow bushes, and those trees overhanging the water, with a gentle swim, five or six feet deep, on the opposite side? Then make for it at once, and approach 
the water cautiously. Take a bit of soft white scratching and put it on your hook, lapping it round the point, and use as much as will press into the size of a common nut. You must not throw any ground-bait in until you have got the right depth. Throw your tackle in, putting it deeper and deeper until the float goes under, then alter it back a little at a time, until your bait swims clear, and about three inches from the bottom. You had better fish with your bait a foot from the bottom than one inch on it. It is quite a mistake to allow the bait to drag on the bottom for any kind of bottom fishing whatever in a stream. The Barbel and Gudgeon require the bait to swim as close as any fish that $I$ know, but even in fishing for them the bait ought not to drag. Did you ever notice the eye of the Chub? If you have, you must have seen that it is so fixed as to enable him to see better above than below him. Go and stand on a bridge, from which you can see Chub lying on the bottom, in three or four feet of water, and throw in a bit of scratching, and if you keep out of sight you will see them rise and take it before it has sunk a foot, proving that they can see anything thrown in long before it gets to the bottom, and that you can catch more fish by allowing your bait to swim three inches from it. Well, having got the proper depth, take a bit of scratching about the size of a walnut, and cut it into very small pieces, for you must remember that although Chub are particularly fond of it, a very little will satisfy them, so that if you were to throw in a number of large pieces, there would not be much chance of your getting a bite, especially if each fish managed to get two or three lumps, which would quite salisfy them for the day. By giving them only a little at a time, you keep them hungry, and are sure to eatch them, if you fish in the right style. Now throw in your small crumbs of scratching three or four yards above you, watching the course of the stream, and the direction the stuff takes, so that you may follow it with your bait to a nicety, calculating also the distance it will swim before it gets to the bottom-perhaps ten or fifteen yards. If you can get the fish to bite at fifteen yards, all the 
better. The further out of sight you are the better and longer they will bite. Now, fetch your line from the second or third ring, according to the distance you wish to throw, and cast, keeping your line behind the float, and as much out of the water as you can, without obstructing or laying the float flat on the water; let your line follow rather tight after it. By keeping the float a little in hand, your tackle and bait will be carried by the stream a little in advance, and if there is a fish in a line with the bait, it will go right into his mouth. If it does, strike gently, otherwise you might cause a break, as your line is nearly tight from the top of the rod to the bait. When you feel you have him, as quick as lightning give him the butt end of the rod, so as to put the hook fairly through his nose, then immediately reduce the pressure, and allow him to go where he likes, unless he makes for a bush or old roots, lying in the water. If he does, you must see which can pull hardest, you or the fish. If you suffer him to get into such places, you will find it difficult to dislodge him, for he will play you the game of "Thread-me-longneedle," running through and round three or four times in a second, leaving your line in a fearful mess. When you have caught two fish, which you will probably do in the first two swims, throw in a little bit more scratching, for I should say you have brought out that first bit with the fish you have killed. Follow this plan up until you have caught them all, or until you have five or six swims without a bite, when you had better seek another place. You need not wait expecting they will come on to take again, for they very seldom will. I do believe that when the day, the wind, and the water is favourable, the angler, if he fishes for Chub in the right style, will, in three cases out of four, catch every fish there is in the place, and very quickly too. For my own part, if I fish a Chub place five minutes without a bite, I go to another swim. I do not believe in the old doctrine of waiting until they come on. No, I have no faith in it. Some Anglers of the old school may say that they would not give a pin for the fisherman who could not stand or sit for twenty hours without a nibble. "Bosh," I can fancy I 
hear those who know a thing or two say, "we would not give the toss of a farthing for the fisherman who would stand twenty minutes without a bite; we once believed in that principle, but all faith in it is now gone for ever." I would not, however, advise you young anglers, who do not thoroughly understand the art, to be too hasty in leaving a place. You may have done something or other wrong; try another dodge or two. That bit of scratching you threw in has perhaps gone down the stream out of your reach; throw in another bit three or four yardshigherup the stream; put a fresh bait on; take a swim of twenty or five and twenty yards; put two or three inches deeper, and fish further out, or a little shallower, and try closer in. Never fish long on one system; alter your style in some way or other, and you may find out the reason why you have not been able to get a bite.

You may fish with pith and brains, in the same style as recommended for scratching, and taking the whole season through, I consider this bait the best of the two, at least I have tested both baits in two or three different rivers, and found pith and brains to be the best. Indeed, in some rivers scratching altogether fails, and even on some parts of the Trent it does not take half so well as pith and brains. As this is a sweet and clean bait, I recommend the Chub fisher to use it when he can get it, in preference to scratching. But whichever bait you fish with, take a towel with you to wipe your hands after handling the bait, for if a bit ever so small touches the rod or line, it will stick to it and mar your fishing. 


\section{THE B REA M.}

Thene are two kinds of this fish-the white or silver Bream, and the gold or Carp Bream. Their flesh is generally considered coarse, and scarcely fit to be eaten, but I am of a different opinion, for I believe the Carp Bream to be a splendid fish, and very excellent food when properly cooked. The other - the white Bream-is, however, very coarse. When small, say about a pound, there is not much difference in the appearance of the two; in fact, it would be a difficult matter to tell which was which. After the white Bream exceeds this weight, it gradually loses its silvery appearance, and becomes of a smoky black colour. This is the common Bream found in ponds, lakes, and almost in every deep river in England. He is rather an awkward customer to kill with fine tackle, but after he is on the bank he is not much cared for. The Carp Bream, after it exceeds a pound weight, becomes of a bright gold colour, which it retains ever after, no matter how large it grows.

Bream spawn about the latter end of May; never sooner, and seldom later. From the 20th to the 26th of that month, they will generally be found spawning. Although they are shy fish, living in deep water all the year round, and often very difficult to catch, they seem to lose all fear at this season. They withdraw from the deep waters, and seek that part of the river or pond which is the fullest of weeds, on the top of which they deposit their spawn. I have seen them when spawning by 
hundreds together, lying with their back fins out of the water, and seemingly indifferent to any molestation ; and $I$ have known a keeper on the Trent to catch no less than eighteen hundred weight of them at this season, at one draw of the net; two of the lot weighed sixteen pounds, and many of them were Carp Bream. They lie in a sickly torpid state for a week after spawning, and then, having regained a little strength, they make for a gentle stream with a gravelly bottom, to clean and scour themselves. They remain there about a fortnight, and then return to the deep still waters, with a clayey, marly, or sandy bottom. Some say they are partial to muddy or gravelly bottonis, but I have always caught them best on the first-mentioned three. There is nothing that will shift them from the deeps except a rise in the water, which will make them retire to gentle streams, about three or four feet on a sandy bottom, in which places I have often had very good sport with Bream.

The Best Months for Bream fishing are July, August, and September, and October, if the weather is fine. I have also caught them well in March and April, but in these two months the water must be coloured and high. At that time of the year they will be found in gentle swims of from three to five feet deep, on a sandy bottom. I have rarely caught them in spring when the water was clear.

The BEST Batts for Bream are the cockspur and dew-worms. Although I have caught a few fish now and then with white paste, gentles, wasp-grub, scratching, and pith, there is, in my opinion, no bait that can equal the worm all through the season. As there is only one method to fish for Bream, and that is to bottom fish for him, if you want to have good sport, you must ground-bait the place you intend to fish the day before, and if you think there is a good stock of fish in the place you have selected, you can give them fifteen hundred dew-worms, allowing twenty hours to elapse after you have done so before commencing to angle for them, when you will be sure to find them in good humour to bite. I remember going to bait a Bream place for a party of gentlemen last September. The water was clear 
and low, and one of the gentlemen, knowing it was all right, said he would accompany me, and fish an hour before throwing the stuff in. I of course said I should be glad of his company. At this time there were about twenty other piscators present, who were laying plans for expeditions against the finny tribe, and the person who was to accompany me said, "Gentlemen, we are going to bait a place in the morning, and I beg to invite you all to a fish supper to-morrow night. Though we shall fish but a short time, I think we can catch sufficient to satisfy you all, so please to remember that supper will be on the table precisely at seven o'clock." "Bosh," "nonsense," "ridiculous," "it won't do," "if I come I shall bring my supper with me," "I will bet a bottle of gin you don't kill ten pounds under the hour," and many more such remarks were made. But the gentleman said, "I shall not lay any bets about it, neither do I care for your chaffing. I have said we shall catch sufficient to satisfy all within an hour, and if the fish are not fortheoming at the time I have stated, then is your time to chaff." On the following morning we went to bait the place, and a beautiful morning it was. The water and everything was favourable, and I felt as confident as the gentleman did that we should be successful. Immediately we got to the water we tackled out, and having got the proper depth, I threw in a few worms, then at it we went. Every swim we had a bite, and in less than half a hour we killed eleven of the handsomest Carp Bream I ever saw, each weighing about three pounds. We now baited the place, and returned home quite satisfied with our sport, and that sufficient had been caught to furnish the promised supper. As soon as some of the party got to know that we had returned, they sent several of the largest frying-pans they could get, and many pounds of dripping. Not knowing what number of fish we had brought home, and thinking that we had got few or none, they sent the frying-pans and dripping as a take-off, but these were very useful, and my friend ordered the fish to be cleaned and cooked, and the supper on the table to a minute. As the time approached, a pretty good number of the Angling fraternity 
assembled, not for the purpose of eating fish (for they were all led to believe that there had been no fish caught), but to give my friend a severe chaffing; and they did go at him and no mistake for about twenty minutes, but he bore it with the utmost magnanimity until the servant entered and announced that supper was on the table. This announcement rather astonished and nonplussed them, and they looked at each other in bewilderment. "Well," said my friend, "you have had a good deal of fun at my expense, it is now my turn, but I propose in the first place that we shall go and partake of the supper that is waiting for us, then as a finisher I shall give you an excellent dessert." We all sat down, about twenty in number, and every one seemed to enjoy himself, for the supper was splendidly got up. After the supper was over and the cloth drawn, the party began to discuss the merits of different kinds of fish. One said he always thought Bream were the coarsest of fresh water fish, and not worth the trouble of cooking. I explained that there were two kinds of Bream, and that the white or silver Bream was certainly little worth, but the fish we had just eaten were Carp Bream, and that I believed them to be rery excellent fish. " $O$, yes," said one, "we have had ample proof of that to-night; for my part, I never eat anything in the shape of fish that I liked half so well." My friend now rose and was about to deliver a tremendous broadside, when several gentlemen got up and stopped him, one of them saying, "No Mr. - we are extremely obliged to you for the supper you promised and which we have all enjoyed very much, and I think I may say for every one in the room that we bave had quite sufficient without any dessert. We are willing to make any sort of apology, or pay glasses round and round again, if that will make things agreeable and pleasant, and atone for the chaffing which we did wrong in giving you a short time ago." "Well," said my triend, "I am satisfied; but I must make one remark: if any of you should come to understand the art of Angling as I do, you will have the same confidence as I had, and find no difficulty in providing a supper of fish when you 
have promised it." The night passed away as it should do when Anglers meet together-pleasantly.

The best method of fishing for Bream is with the float, and as you can catch Bream both in deep and shallow water, you will require different tackle for each. For a deep water of from twelve to fourteen feet in a stream, the rod, reel, line, float, tackle, and hook recommended for Barbel fishing will be more suitable than any other. When you fish in a water from four to eight feet deep, the rod and line recommended for Chub fishing with a quill float, that will carry five or six B.B. shot, and a No. 7 hook will be most answerable You can fish either with a cockspur worm, or the tail end of a female lob with this tackle.

\section{THE ART OF BOTTOM FISHING FOR BREAM.}

I will first give directions how to fish for Bream in a river in deep water with a gentle swim; then in a gentle stream of four or five feet, where they will be found when there is a rise of water; and lastly in deep stagnant pools or lakes.

For fishing a place twelve feet deep in a stream, you will require the tackle I have recommended for Barbel fishing, but always fish with the smallest float that the water will admit of your using. If you can fish with a large turkey or swan quill, do so; if not put on as light a cork float as you can fish with, for the lighter the better. We will suppose the time to be July or August, the bait you are going to use to be dew worms, and the place you are going to fish to be ground baited with the number of worms I have already recommended. The water should be clear and low and the wind blowing behind you. You should get the proper depth and measure it on your rod the day you baited; this will save a good deal of trouble afterwards, and prevent you from disturbing the fish just before you commence to angle for them. Bream is a bottom fish you must remember, and you must allow your bait to swim as close to the bottom as you can without touching it. Now cut up 
twenty dew worms into bits an inch long, and throw them in, spreading them as little as possible, so as to keep the fish together, and all in one channel. Allow for the stream and the depth of the water, so that the worms may get to the bottom eight or ten yards below where you are to stand to fish. As soon as they get to the bottom every bit will be devoured. Now put on your hook a well scoured lob, allowing half an inch of the bait to writhe about, and send it in the same direction that your ground bait has gone, and it is almost certain you get a fish the first swim. When you are going to throw, fetch your line from the third or fourth ring as may be most suitable for the distance, and east in the same direction as you have thrown the worms, holding your rod in your right hand, and giving line with the left, in such a way as to keep the float going rather tight, so that your bait may swim first. When you perceive a nudge, do not wait until your float goes under, but strike at once, for it often happens that the largest fish bite the shyest. This style of Bream fishing resembles Barbel fishing, and I have often caught both fish in the same swim. If you should get them on the bite with the first bit of stuff, then you will know that you are fishing the place in the right style; but if not, having the wind and water all right, you must have done something or other wrong. You may suppose there are no fish in the place, but that is not the case. I have known parties to fish different places for hours, and even days, and catch but very few fish, and yet after they had dủne angling and gone away with the idea that there were no fish in the water, I have fished the same places, and had splendid sport for two or three days in succession. Now, instead of coming to a hasty conclusion, commune with yourself. The water is very clear and the sun bright. You may have been fishing too close in. Throw in a few more worms lower down, and further out, and take alonger swim. It is perbaps deeper further out; alter your float three or four inches and put on a fresh bait. Now they are biting every swim. By doing everything you can think of to discover the reason of your non-success, you have at last found it 
out. As I said before, if there is only one thing wrong all is not right. Now that you have got the fish on the bite, be very careful how you treat them. Do not dash worms in after every fish you kill. Catch three or four and then give them about twenty worms, for the fewer you throw in the longer and better they will bite.

There are several Bream holes that I know that are from twenty to thirty feet deep, and you would find it difficult to fish these places unless you understood fishing with the sliding float. With the slider you can fish any depth with the greatest ease. Some of my readers may not know how it is made or worked. I will explain. This float is made the same as the cork float for Barbel fishing, long and thin-a little larger than one you fish with in water eight or ten feet deep. Fix two rings, just large enough to allow your line to pass freely through, one almost at the top and the other at the bottom of the float, taking great care that they are in a direct line with each other. When you intend fishing with this float pass your line through both rings, then put on your corking weights, and tie the tackle on. Now you observe the float rests on the corking weights. Let us suppose the water is thirty feet deep; allow the float to remain where it is and measure thirty feet from the hook up the line, at which distance make a drawn noose in the line, and put a small bit of india rubber or line in the noose and draw it carefully up, so that you can shift it out again if required. Now wind the line up and throw from the reel; as soon as the float drops give it line slack so that it will pass freely through the rings on the float till it gets to the knot; when you wind up the float will go back again to the weights. I must not forget to mention that you must have fast rings on the rod to allow the knot on the line to pass freely through. You will find this float excellent fordeep water, both for Barbel and Bream fishing.

When there is a rise of water and Bream leave the deep holes, they will be found in gentle swims three or four feet deep. You should mark out when the water is low and you can see 
the bottom, such places as may be suitable and are free of weeds. You will then know where to go to at once, and aroid much trouble. If you fish for Bream in March or April, the shallows are the only places you can eatch them in, for there are none in deep water. It is of no use ground baiting in spring; the worms are too cold, and a very few bits will satisfy them. But in the summer months in this kind of water you should give them five or six hundred dew worms cut into bits an inch long, because large Roach and Perch resort to the same places, and the tackle and bait recommended for fishing such places for Bream are also suitable for them. Having got tackled out, get the proper depth, allowing your bait just to miss the bottom, then cut four or five dew worms into bits about the size of horse beans. If the stream be slow throw them in about a yard above you, and they will get to the bottom three or four vards from where you stand to fish. Now put on two inches of the tail end of a well-scoured female lob, and be careful how you move on the bank, for the least shake will drive away every fish in the place. Fetch your line from two or three rings up and make a cast the same distance as you have thrown the ground bait. As soon as you see the float rising, lay the line behind it, so that your bait may swim first. If the fish begin to bite, give them no more worms until they begin to fall off, then throw a few more in. If you do exactly as I have told you there is no doubt but your sport will be good. It was in this style, and with this kind of bait, that in 1855 I caught eightyfour pounds of Bream, in four hours, on the river Lee, near London.

In deep stagnant waters the first thing you should do is to find out that part of the pond, lake, or whatever it may be, which is freest of weeds, and has nothing foul on the bottom. Then ascertain the depth and allow your bait to lie two or three inches on the bottom. This is the only kind of water in which I recommend the bait to lie on the bottom, and the reason I do so is, that the worms you have thrown in have gone to the bottom, and must remain there until the fish find them, and 
by allowing your bait to lie two or three inches on, the fish pick it up the same as they would the ground bait. Some of my readers may say, "You are now fishing with the bait on the bottom to imitate the ground bait; why, then, not do the same in a streain? the worms you throw in roll on the bottom until something stops them, and to initate this the bait should drag two or three inches on the bottom." My answer is, that as the bottom part of your tackle swims first, the bait would run against the nose of any fish that lay in the way, and compel him totakeit, but by allowing it todrag, evenif he should happen to see it passing, he must turn round and swim after it before he can take it; then if the fish are eager and keen to bite, the head of the worm which goes 'first when the bait drags, is sure to be snapped at, and when you strike you miss the fish and spoil the bait; again, when the hook is dragging it is liable to catch anything foul lying on the bottom, and in my opinion the odds are a hundred to one against a dragging bait. In the style I have recommended the bait goes first, the tail writhing on the point of the hook. Is it likely that a fish would shift out of his place to allow it to pass? I should think not. It is like poking your fist into a man's face, and daring him to come on. You see fishing in a stream and in still water are two different things. Now, having got the right depth, cut tliree or four dew worms small, and as mary cockspurs into two pieces, and throw them all in together in the place you intend fishing. Then take two good sized cockspurs and put your hook in at the head of the first one, and out half an inch from the tail; draw it up the gut and put the hook in the other a quarter of an inch below the head, and thread it to a quarter of an inch of the tail, then draw the first one carefully down to it, and you will have a very attractive bait for pond fishing. Now, whether on a bank or in a boat, be very still, and make a cast to the place where you have thrown the ground bait. The moment the bait gets to the bottom the chances are that the float goes under. Throw in three or four dew worms about every twenty minutes, and I have little doubt you will return satisfied with your sport. 


\section{THE ROACH.}

This is a handsome, game little fellow, but perhaps the coarsest fish that swims in fresh water. Roach fishers are, however, very numerous, and increasing every year. in fact, I believe there are more anglers of this fish than of any other, and he certainly affords good sport, and it requires no small amount of skill to take him; but there is not one out of ten who angle for him that fishes in the right style, and with the proper tackle. Many think that anything will catch Roach, but they generally find out their mistake.

Roach spawn at the latter end of May, and deposit their spawn on the top of weeds in shallow water. I have frequently seen them in hundreds, I might say thousands, together, with their back fins above the water, spawning on the top of weeds. I have often watched them in shoals repairing to the spawning ground, and fighting against strong currents until they had found a suitable place. Roach are very quick over their work, three or four fine days taking them away from their spawning places. They then seek a shallow stream with a gravelly bottom to scour themselves, and at this time, if you have a mind, you may whip at them with the fly and catch any quantity, for they will rise eagerly. I have frequently caught three and four with one cast. It matters little what sort of fly you fish with, they seem to take one as readily as another. All fish more or less become stupified at the spawning season, but on the first 
return of consciousness they will run at and bite anything that comes in their way, and this applies to Roach as well as to most other fish. Roach are not partial to strong streams at any time of the year, and after they have done scouring, you will find them in gentle swims of from three to six feet deep, but the largest fish will be found in deeper water. I once picked ten Roach from a basket that I caught in one of the summer months (I think it was in the latter end of August,) that weighed fifteen pounds-the largest fish weighed two pounds and three ounces. These were all caught in about eight feet of water with the female lob-worm. I think I never saw a dish of finer Roach in my life. From October till March they will be found in still water with a sandy bottom, sometimes a gravelly, but never a muddy bottom.

The baits for Roach fishing are very numerous, and some Roach fishers are very whimsical about their baits, using different kinds of colourings, sweeteners, and scents. - But if you want a scent you cannot have a better than I have recommended for Barbel fishing. I will name most of the baits used for Roach fishing, and then I will tell you which, in my opinion, are the best. Artificial and natural flies, gentles, straw-bait, cad-bait, wasp-grub, creed malt, and wheat, grains, creed rice, and pearl barley, white and red paste, red worms, and the tail end of the female lob. All these baits will eatch Roach at certain periods of the season, but not at all times. For instance, it would not be advisable to fish with flies, grains, creed malt, and wheat, in the coldest winter months.

I will here relate how I took the conceit out of a boasting Roach fisher, and convinced him that his style of fishing was wrong and his fanciful baits useless. In the year 1850, when I resided at Derby, I mado tremendous havoc amongst fish of all descriptions, which made many Anglers very jealous of me, one in particular. He said, "I will fish this man for what he likes; I don't eare who he is or where he comes from; he may be a good fisherman, but I think I can lick him at Roach fishing." An uncle of mine, who was present, hearing this challenge, 
accepted it at once, each to fish with what baits he thought proper, both to fish on the same mile of water, and to keep twenty yards apart. The match to be for the greatest weight of Roach, no other fish to be weighed in. The 22nd or 23rd of August was the day appointed, and we both started off to the Trent, five miles from Derby. On arriving at the place I proposed a glass of ale, but my opponent would not agree to that, being very anxious to commence work, so I told him to go on, and I should be with him in a short time. I staid and had my glass of ale, so that he had about half an hour's start of me. When I joined him I saw a spread on the bank that astonished me: there, on a cloth, lay arranged, in perfect order, gentles in a tin box, grains, creed malt, and wheat, white and red paste, and a piece of white bread -baits which I considered sufficient to catch all the Roach in the Trent if properly fished with. After taking stock of this display, I enquired what sport he had had. "I have not got them together yet," he answered, "I have only caught one about two ounces; they will come on to bite presently, and then I shall have plenty to do to bait and take the fish off the hook." I then left him and went to seek out a place for myself. The water being a little coloured, and three or four inches higher than usual, I selected a gentle swim on a gravelly bottom, about three feet deep. All the baits I had, and all I cared for, were about two hundred dew worms. I was quickly tackled out, with a nice light rod, fine silk line, small quill float, No. 8 hook, baited with the tail end of a well-scoured female lob. The style of fishing I will give you by and by. Well, every swim I had either a fish or a bite of Roach, Dace, Perch, or Chub, but chiefly Roach. I commenced at half-past ten, and at one o'clock I found I had at least twelve pounds of Roach, besides other fish. I then lit my pipe, and made up my mind to take it easy. While I was enjoying my smoke, up came my antagonist, who asked me what sport I had had. I answered, that if the fish continued to bite as they had been doing, I should catch a good number before the time was up. I asked him if he had caught any more. "Very few," he replied, 
"perhaps eight or ten little things." "Why," said he, "you are fishing with worms, and I never thought of bringing any with me." They seem to prefer worms to-day to any other bait ; we never know when to have them; sometimes they fancy one bait and sometimes another. You must let me have some of your worms, and you can have some of my baits." Well, I thought, here is a liberal offer: this looks something like being licked, but its no use doing the thing by halves, I may as well kill him with kindness, so I said you are welcome to some of my worms, and as your float and tackle are not quite the thing for worm fishing, I will lend you one. He accepted this offer, and I arranged it for the proper depth, telling him he might fish the same swim in which $I$ was angling. He said that would be against the regulations, as we had agreed to fish at least twenty yards apart; but I quieted his compunctions by telling him that as I consented to it, no fault could be found. We then fished in the same swim, and he caught the fish as quickly as I did, to his great delight. I then left and went to fish a swim thirty yards below, where in a few minutes I got them to bite as fast as in the first place; but they went off biting in the place I had left ten minutes after I was gone, for the simple reason that my opponent never thought of throwing in a few worms. He quickly packed up his traps for the purpose, as I thought, of going to fish another place. But I was mistaken, for he went behind a hedge, lapped up his tackle, and bolted home as fast as his legs could carry him. When I found this to be the case I packed up and went after him, but could not overtake him. At this time it would be about half-past two o'clock. When I got home I went to my uncle and showed him what I had eaught, and told him what had occurred. He weighed the fish and found there were seventeen pounds of Roach, and six or eight pounds of other fish. He then went to my opponent's house and asked him why he ran away. "Oh," he said, "I give in that I have been fairly beaten, but it was unfair on your friend's part to go away and take all the fish with him; I scarcely got a bite after he was gone." 
I do not recommend the worm as being the best bait for summer fishing. On the contrary, I know several rivers in which fishing with the worm for Roach would be a perfect failure; you would probably not catch a fish in a week. For instance, I fished the Thames and the Lee for five weeks with the worm, and during all that time, although I caught almost every other kind of river fish, I did not get a single Roach. I put on suitable tackle, and fished likely places, but it was no use, every other fish took the bait freely, but no Roach touched it. I could not account for this, because I knew there were plenty of Roach in both rivers: until one day, when fishing from the bank at Hampton Court, I saw on the opposite side a nice swim. By wading over a small backwater I could get to it, so I doffed my shoes and stockings, and when I got into the water I was astonished to find it as cold as ice. I have stood in the water for hours together, but I could not have stood that for five minutes. I then thought it was no wonder Roach would not take the worm. The cause was at once discovered. I found out that the Thames water was of about the same temperature as the Derwent and Dove, being twice as cold as the Trent, and the Soar and the Idle, in which Roach take the worm well nearly all through the summer. It is no use fishing the Dove and the Derwent with the worm for Roach, except in winter. I have not fished the Thames in winter, but I have no doubt Roach in that river would then take worms as well as in the former two. I have studied to find out the reason why fish would not bite in one river as well as another, and I feel sure the cause is, that the water of one river is much harder and colder than another. In my opinion, you cannot fish with a better bait for Roach for the first two or three weeks after spawning than gentles, and indeed all through the summer you can take Roach with this bait more or less. From the latter end of July to the end of September, creed malt and wheat are very good baits, with grains to throw in. White and red paste are also good, with chewed bread for ground bait. From October till April the red worm or cockspur, and white paste are the best baits. 
The Rov for Roach fishing should be eleven feet long, and as light as possible. A two inch reel will be large enough. The line may be any length you please, but I would recommend it to be no less than one hundred yards, as larger and more difficult fish to deal with might sometimes take your bait. It should be made of all silk, one hundred yards to weigh about two drams and a half. The smaller your quill float the better; one that will carry two or three small shot (the bottom one a foot from the hook,) if you can work it will be very suitable. Some Roach fishers are partial to the single hair, but as you can get gut as fine as hair I don't see the advantage of it. You can see a hair in the water better than you can gut, and why it should be fished with I don't know, unless it be to give the best fish a chance of getting away. At one time the single hair was a great favourite with me, and I once killed a Barbel four pounds weight with one, but it took me twenty minutes to land him, and I felt him to be very unsafe until I got him on the bank. I have lost many good fish by using the single hair, more than I ever shall again, for experience has taught me that fine gut is decidedly the best for any sort of water. The hooks for Roach fishing should be No. 10 for gentles and white or red paste, No. 12 for malt or wheat, and No. 8 for worms. There are various opinions held as to the size of hooks, but I think these are better than any other. You may ground bait the place you intend to fish the day before. If you are going to fish with gentles, bait the place with two quarts of small gentles; if with creed malt or wheat, bait with three quarts of fresh grains; if with white or red paste, bait with half a pound of soft white bread, and half a pound of boiled rice, kneaded well together; and if with worms, bait the place with five or six hundred red worms of all sorts cut in two. The only period of the year to ground bait is from July till the end of October. After this ground baiting is useless.

\section{THE ART OF ANGLING FOR ROACH.}

Under this head I will describe how to fish with gentles, with 
creed malt or wheat, with worms, and with white or red paste. I shall suppose that the water is clear, the wind blowing behind you, and that you have selected a gentle swim from three to four feet deep. Get the proper depth and fish so that your bait may swim two or three inches from the bottom, never on it, for you must bear in mind that Roach can see better above than below them. Now sit down and be very still on the bank. Throw in about twenty small gentles (pick the large ones out) two or three yards above where you sit. In a small box you have got some gentles of a better kind, that you have kept purposely for the hook. Take two, if they are not large, and put one on to cover the shank, and the other the bend of the hook. Sit well back and keep as much out of sight as you can. Now make a cast the same distance out as you have thrown in the ground bait, so that your float may swim to a nicety in the same direction as the ground bait has gone. Let your line swim behind the float, and as much out of the water as possible, letting the float go steadily down the stream as if there was no line attached to it. As your line is very fine, it will glide free and easy through the rings. You may occasionally take a swim of six or eight yards. If the fish should not come on to bite in ten minutes after throwing in the first few gentles, give them as many more, and if this does not take effect, put about twenty inside a small lump of clay; these will go to the bottom at once, but this style of ground baiting, although very good for boat or punt fishing, makes too much noise when the lump has to be thrown in from the bank, and if you can get the fish to bite by throwing a few gentles in alone all the better. But sometimes this is useless, as a shoal of Bleak may be swimming a foot from the surface, that eat up all gentles when thrown in long before they get to the bottom. If the fish should bite after the first lot of gentles, throw in a few now and then, say about a dozen every five minutes. If you have good luck, you will bring out all you throw in with the fish you catch. If there is a good stock of Roach in the place you are fishing, you can keep them on the bite as long as you like-at least, I could.- 
The style of fishing with creed malt or wheat differs little from the above, but I have seen so much bungling on the part of Roach fishers with malt that I shall endearour to correct them. I have seen them fish sharp streams, and boiling eddies ten or twelve feet deep, with their bait but a yard below the surface, and throw in grains for ground bait, and not a few either, but five or six handfuls the first start. "Of course, after throwing in such a large quantity of ground bait, it is impossible to get a nibble, for the fish have all gorged themselves. I have known this piece of folly to be committed both on the Trent and Thames a hundred times. The Londoners mix up a fearful mess for ground baiting with while fishing. I have seen one of these messes mixed up by a gentleman in a punt at Chertsey bridge, on the Thames. After he had tried my style of angling, and found he could not manage the running line and a reel, which ran too quick for him, he gave it up. I pressed him to try again, and he did, and caught two or three fish, but he would not continue the style; so I went with him, not to instruct him, but to look on and learn something that I had not known before, for he said, "Now, master fisherman, we will show you our style of angling, and how to catch Roach and Dace by wholesale; bring that tub here." I did so, and found it was full of clay or rather slug. He now took off his coat and turned up his sleeves, made a hole in the middle of the clay, and put in about a quart of bran, two pounds of soaked bread, one quart of gentles, two or three handfuls of greares in lumps, and two or three hundred of chopped dew worms. He then kneaded the whole together as a baker would knead his dough, and having completed this process, he formed part of it into two or three large balls, and dropped them carefully over the punt side. Of course they went to the bottom at once, but as soon as these dumplings dissolved the water became a living mass with the different sorts of stuff that the ground bait was composed of, and I could see that a deal of it would go down the stream for a hundred yards, and that there had been sufficient thrown in to satisfy all the fish within a quarter of a mile of the place. I 
could not help laughing at this performance, and I thought if that was the London style of ground baiting it was certainly a very absurd and ridiculous one. When the gentleman saw that I was laughing, he said, "You may laugh, but we will show you a bit of Roach fishing that you don't often witness." "Well," I said, "I hope you may, but I very much doubt it." "Why," asked he. "Because," I replied, "in ten minutes there will not be a fish in the place that would thank you for the best bait you could put on the hook, for the simple reason that you have thrown in such a medley of stuff, and such a quantity, that the fish will be perfectly gorged." "Nonsense," he said, "there is plenty of fish here, and I shall give them as much more in about ten minutes." "Well," I said, "we shall see what effect this first lot takes." So at it they went, a gentleman and a lady.

First round.-After a good deal of dodging, her ladyship let fly a beautiful right hander, which nailed one on the conk, drawing the first blood.

Second round.-A little cautious sparring for about a minute, when the gentleman made a slashing upper cut with the right hand, which told with etfect on the nasal organ. He claimed the first knock-down, but, unfortunately, the force of his blow broke his tackle.

Third round.-Rather slow at getting to work. The gent came up rather flushed and excited from the effects of hitting in the last round, and after a few harmless taps on both sides they pulled up.

Fourth round.-In this round some good hitting took place; one napped it on the beak the other under the chin, a breakaway and at it again, when the gent succeeded in planting one, two, on the mouth, and was about to administer another spank, when her ladyship sent out a straight one, and nailed him on the snuff box. This brought it to a close.

Fifth round.-The hitting in this round was all in favour of her ladyship, for she succeeded in probing him three times in succession on the breather, and got clear away without a return, 
Sixth round.-It was now very plain that the gent had not much chance, for the odds were against him catching much fish. Her ladyship caught him once more on the potatoe trap, and another on the snout, and got clear away.

Seventh round.-On time being called, it was evident the biting was all over, and he had not a shadow of a chance of winning; having got his tackle ravelled, he gave up licked. I then threw up the gentle bag in token of defeat, and Mrs. Fish was hailed the winner. Thus ended one of the worst exhibitions of fishing I ever saw. Only fourteen sprats were caught, which did not weigh in all above two pounds. The gent said it was not a Roach fishing day, that the sun was too bright-a common excuse with anglers when they get licked by their own bad judgment.

There are some writers on angling who recommend this ground bait, with several other additions to it, for all sorts of fish that require ground baiting; but $I$ am of opinion that it is a piece of advice given without knowledge. I will state a few facts, and leave them to the judgment of my readers. In the first place, if you have baited a place with gentles for Roach, what bait do you fancy will catch him best after such a baiting? What do you think of the worm? do you think it would catch him better than any other bait? No, certainly not. He would not take it; gentles would be the best. Very well, suppose you bait a place with worms, should you fish it with gentles? By no means. Now, say you bait a place with greaves, and another person comes three or four hours after you, and gives the fish two or three quarts of gentles, and another follows and throws in a lot of worms, what bait would you fish with next day? You cannot tell, nor can you invent one which the fish will take. Then suppose you bait a place with bran, soaked bread, and gentles, you would not think of fishing with worms; it would be absurd to do so. Well, take the London style of ground bait altogether, and add what more you like, what bait would youput on your hook? Gentles, you say, why not fish with the worm? Because they would not take it so well you reply. 
Then, I ask, what is the use of throwing in worms, or any other sort of bait, if they prefer gentles to all the rest. I cannot tell what purpose this mixed medley serves. The very person who recommends it, tells the angler to see that no one cross bait the place after him, while the mess of itself is a cross baiting. I am certain, if any angler ever did catch fish after a baiting of of this sort, that he would kill ten times as many if he baited and fished with one kind of bait. I have not made these remarks with an ill feeling towards any one, and I should be sorry if it would be taken in that light. The sole purpose $I$ have in view in writing this book, is to give the result of my own long experience on fishing, so as to benefit the angling fraternity.

In fishing with creed malt and wheat, the same tackle may be used as that recommended for gentles, but the hook should be No. 12, instead of No. 10. It is a grand point, not only in Roach fishing, but also in every description of angling, to tell the likeliest places in which to find the fish at different times of the year. For these baits the water must be clear, and a gentle swim from three to five feet deep. Let your hook be short in the shank, and lapped on with silk, so that you may bury it in the bait. Get the right depth, allowing your bait to swim two or three inches from the bottom. Sit down and be very still. Take a few grains in your hand and pick the whole ones out, throwing the remainder in two or three yards above where you sit. Now put on a bait and make a cast. Keep your line behind the float, so that the bait may swim first, and allow the float to swim as steady as possible, for if it goes tottering along the bait will go through the same movements, making it more difficult to catch this shy fish when the water is clear. If they come on to bite, give them a few more grains every ten minutes. When you hook a good fish, keep it under the water, and get it out of the place where they are biting as quickly as possible, landing the fish above where you sit without getting up, for your success depends much on your being quiet and still on the bank.

The same rod and line will suit fishing with red and white 
paste, but the float should be smaller, and the hook No. 10 . It does not matter much about the colour of the water, so long as it is not too thick. For my own part, I prefer it being a little coloured. If it is so, a water of three feet deep will be quite sufficient. I should recommend you to take both baits with you for summer fishing, for the fish will sometimes take one and then the other, and the change will often work a difference. Select a water nearly still, for if there is a move either one way or the other it will be sufficient. Get the depth, allowing the bait to swim two inches from the bottom. Sit down of course to Roach fish, unless you are fishing a great distance from you. Chew a small piece of white bread and blow it in, if you can, to the place you intend fishing, and repeat this every five minutes. You will find this to answer the purpose better than throwing in two or three lumps the size of a potatoe. If the fish don't come on to bite in twenty minutes, I should advise you to seek another place; but before you leave, see that you have been fishing the place properly. One little manœuvre will make a difference. Alter your float a little higher or a little lower, fish closer in or further out; throw in a little more ground bait in another place. Give the place a fair trial, then if you find the fish do not bite seek another. White paste is an excellent bait for Roach all through the winter till April.

The worm is more suited for winter fishing for Roach than for summer fishing, although I know several places on the Trent where Koach take the worm well in August and September, but I consider October and November as good or even better than any other two months in the year for Roach fishing with the worm. I have, however, caught Roach in every month of the winter when the water was as clear as gin, and freezing sharp, and also when there has been a rise of water and coloured. In winter if you fish when the water has risen, it must be when it is caused by rain, and not by "snow-broth" as it is called. It matters not how fine the water is, so long as snow remains in it fishing is useless. If the water be risen, and a little coloured, seek a gentle swim, with a sandy or gravelly bottom, and from 
two to four feet of water. If the water should be fine and low, from three to six feet deep will be a suitable depth. The same rod and line will do for this bait as the last mentioned. The float should be as small as possible, and the hook a No. 8. You should fish with a cockspur worm, but any kind of red worm will suit for ground bait. There is a worm that we call the leen-worm; it is of a blood red colour, and about three inches in length, not very tough, but it is the best ground bait that can be used for Roach. Get the depth so as to allow your bait just to miss the bottom. Cut three or four red worms into bits the size of peas. You cannot cut them too small for Roach. If you are going to fish a gentle stream, allow two or three yards for the worms to swim before they get to the bottom. Now make a cast and see that your bait follows the ground bait to a nicety. I have often found the fish bite better in the middle of winter without throwing anything in. At least I always try to catch them without ground baiting, and if they do not bite, I give them only a few worms, as I know a little will satisfy them when the water is cold. 


\section{THE DACE.}

After the many days' good sport I have had with this little fish, and the thousands I have caught, $I^{\prime}$ cannot do less than say a few words about him. I believe him to be the keenest and boldest biter of the finny tribe. It indeed is surprising to see how he will smash a nice red worm without even touching the hook. I have seen Dace bite every swim when the water was clear and low, and the sun bright, and nibble the last bit of worm off the hook, and yet escape being caught; but when the day is cloudy and the water coloured, his bite is sure, and if you are smart you may catch nearly every one that nibble. $\mathrm{He}$ will rise at a fly boldly, and I have often caught three and four at a cast, but sometimes you will not be able to catch one; his eye is good, and he can detect the deception you are using in a moment. If any one is desirous to become a good bottom fisher, let bim practice fishing for Dace; he can learn the art of angling sooner and better by fishing for Dace with the worm than for any other. The first four years of my angling experience was devoted almost entirely to Dace fishing, and I can assure you, had I not done so, I should not have known how to kill the finny tribe half so well as I do at present. I have caught every description of fresh water fish in one day's Dace fishing with the cockspur. I once caught a Ruffe, and in the very next cast a Chub six pounds weight with the same bait, and it is the uncertainty of telling what fish may bite next, that makes Dace fishing so amusing and exciting. 
Dace spawn in the latter end of March, in a gentle stream with a sandy bottom. This is the only fish that I know that will bite while spawning. I have seen them in thousands together on sand beds at this season rise at the fly, and bite at the worm as fast as you could throw in. Sinme will be caught just after parting with their spawn, but I have seen the spawn run away in a stream the moment they were touched. But it is not sportsmanlike for anglers always to eatch fish when they can. Give them sufficient time to recover from spawning, say one month, and then it will take all the skill you possess to catch them. As soon as Dace have done sparning, they make their way to a sharp stream with a gravelly bottom to scour and clean themselves. This occupies the best part of April. From the beginning of May till the end of September, they will be found in deeper water, but always a good stream. They do not like still waters during the summer months. In October, when the frosty nights set in, they retire to a gentle swim, from two to four feet deep, with a sandy or fine gravelly bottom, where they will continue all winter. Dace will bite when it freezes in very slow and languid streams.

The best months for Dace fishing are those from July till November inclusive, but the fish will bite at certain baits more or less every month in the year, but in my opinion the best months are those which I have referred to, because after November Dace fishing is far from being certain, especially if a little snow should get into the water. If so, cold worms do not very well agree with them; in fact, a very little food of any sort will satisfy them in the winter months. Dace are caught with many kinds of baits, and anglers differ much in their opinions as to which are best. The principal baits used are the cad-bait, straw-bait, wasp-grub, gentles, grains, creed malt and wheat, flies, and worms ; but, in my opinion, if you were to fish with five hundred different sorts of baits you would find none equal to flies and worms. There is no doubt but Dace will take all the above-mentioned baits, but even when they will take any of the first seven, the last two will catch them better than all 
the others; so, at least, I have always found. An occurrence, which I shall here relate, will give you a hint or two about worm fishing for Dace. I remember going to Willington, a noted locality on the Trent for angling, some seven miles from the town of Derby, to fish a "capital place for Barbel. Before I started I looked at the weathercock (as all anglers should do) to see if the wind was right, and finding it was, off $I$ went. When I got to within two hundred yards of the place, I met a fisherman returning home. He said, "It is no go, the fish won't bite this morning. I have been fishing since five o'clock, and now I suppose it is ten, but I have not had a single bite; the water is too clear. If I were you I should go home, for I am sure it is no use fishing." I said, "It will never do for me to go back after walking seven miles, without having a try; I must be convinced as you have been." "Well," he said, "I will go down with you, but I doubt you will do no good." So we went away together. I was quickly tackled out, and I think I never felt more confident in my life, for I saw that everything was in my favour. I got the depth, threw in a few worms, and in the second swim killed a Barbel three pounds weight, and five more very quickly, all of which the fisherman landed, expressing great astonishment. "Barbel bite well," he said, "that is certain, but I have been fishing for Dace, and it is a great certainty they won't bite." "Well," I said, "if you will wait a short time longer, I will go with you and try the place you have been fishing." "Very well," he answered, "I shall bet you two glasses of ale you don't catch two dace out of the place in half an hour." I agreed to this, and after I had caught twelve Barbel, I found I had got as much as I could carry, so I tied up thelbasket handles and went with him to the place that had licked him. As soon as I got to the spot, I asked him what baits he had been fishing with. He answered that he had first tried gentles, and then the worm, but never had a bite. I took off the Barbel tackle and put on suitable tackle, and "float" for"Dace fishing. I then asked him to give me what worms he had left, which he did, and offered to double the bet, to which I agreed. He took 
out his watch to time me, and in the first fifteen minutes I caught eight fine Dace ; by the time the half hour was up, I had caught twenty. I had no occasion to speak a word, for I never saw a man so stunned; the colour went from his face, and he stood aghast. At last he said, "You may fancy how disgusted I feel with myself at my conceit in thinking I was a fisherman, and that because I could not catch them no one else could. Now you have taken the worms from the same bag and caught this lot of Dace. I will sell off my fishing tackle this very day, and renounce the craft for ever." I told him not to be too hasty, and that it only required a little practice to make him a good angler; but he would hear no reason, so I put the Dace in his basket, lapped up my tackle, and went to get the glasses. In all my fishing excursions, I never saw a man so much amazed as he was. I have seen him several times since, but he says he will never make another attempt at fishing so long as he lives.

You may ground bait for Dace the day before you fish, with five or six hundred dew worms, but you must remember when you are baiting for Dace, you are doing the same for all other kinds of fish, for there is not a single fish that swims in fresh water but will more or less take the bait.

The Rod for Dace fishing should be twelve feet long, and very light, the lighter the better, if the action be in the right place, and it strikes sharp from the top. A three-inch common reel, varnished to keep the rain from swelling the wood, is most suitable. One hundred yards of line for this style of fishing should weigh three drams, not a fraction more, else it will be too thick. Your tackle should be fine gut, one yard long, and your hook No. 8. Let the bottom shot be one foot from the hook. You will require a quill float, but the size must be regulated according to the stream and the depth of water in which you are going to fish, but it should be always as small as possible.

\section{THE ART OF BOTTOM FISHING FOR DACE.}

When the water is clear and low in summer, select a swim from 
four to eight feet deep, with the stream no stronger than will prevent your fishing with a turkey or swan quill float, that will carry not more than six or seven B.B. shot. Never use a cork float for Dace fishing. If you fish with the line I have recommended, you will find a four shot float sufficiently large to fish Dace swims in general. For summer fishing I would advise you to fish with the tail end of a well-scoured female lob. This worm wears better and stands more tugging than the cockspur, and Dace will take it as weil, or perhaps better, in the summer months, though not from October to March. See that your baits are well scoured in moss, but the worms you intend throwing in or using as ground bait are better unscoured, as it is desirable to have the worms for the hook in better condition than the ground bait. I shall suppose you are going to fish a water six feet deep, but don't make the attempt unless the wind is at your back. If it does not do so on one side of the river go to the other. This is always a great point, and, indeed, it is impossible for any one to fish for Dace with the wind blowing in his face, or down the river. Now get the depth, letting the bait swim as close to the bottom as possible without touching it, and fish that part of the swim that has the levellest bottom. Although your float should go under in one place you may not be too deep, for it may be a bunch of weeds or a large stone in the swim that catches your hook. Lift your float and let it swim again, and then you will see whether it is the bottom, or anything foul lying upon it, that brought your float down. If it should be merely a stone, or a lump of something or other, and you put shallower to miss it, you may be fishing with your bait perhaps a foot from the bottom. This is a common reason why anglers return home with empty baskets, and you must therefore remember to examine the bottom well before you commence fishing, and avoid the foul places by going a little above or below, for unless you have a level bottom your chance is but a poor one. I remember fishing a Dace swim with a gentleman on a foul bottom. I could not imagine what lay on the bottom, but it was certain there was something standing at least a foot 
high, and about half way down the stream. We would have stood five or six yards higher up or lower down, but we could not, as we were fishing in a hole several feet deep, with only about three feet of water above and below it. We were therefore compelled to keep our ground. I got the right depth of the hole, and every time the float got to the spot I put a little pressure on, and allowed the under current to lift the tackle and bait over the foul place, and then let it swim again. Strange as it may seem, nearly every fish bit as soon as the bait fell on the other side of the lump. I killed about twenty Dace and two Barbel before my friend caught a single fish. He could not understand what the matter was, as he was fishing the same swim with the same sort of tackle and bait as I was. I suspected what was wrong, and asked him to measure depths. We did so, and he was twelve or fourteen inches shallower than I was. I explained to him that he had mistaken the foul place for the bottom, and that his bait was not near the fish. He was not the only one who has been licked by an uneven bottom; it is a common occurrence, and unless you can make sure that you are fishing the proper depth, you will never be a successful angler.

We will suppose the bottom is level, and that you have got the depth. Well, then, cut five or six dew worms into small particles, and throw in above where you stand to fish, but how many yards above you I can't tell. You must regulate that according to the stream and depth of water; but if it be six feet of water you are going to fish, and be what we call a steady swim, two or three yards above you will be sufficient. If the water runs about the same depth eight or ten yards below where you stand to fish, and the ground bait swims that distance, it does not matter, as you can with care let your float swim after it with that fine line. In fact, the further away you fish the better, as the water is clear. Put about an inch of the tail end of a well-scoured female lob on the hook, and make a cast the same distance in as you have thrown the ground bait, so that your bait may follow exactly in the same direction. Let the line 
swim behind the float, so that the bait goes on first. Be careful always to keep your running line free, for although you are Dace fishing, a Barbel or any other large fish might come, and if your line is not clear, you may guess the consequences. If the fish come on to bite at once, fish until they get rather backward, and then give them a little more minced worm, but take care to throw it in exactly where you threw the first lot. Be careful how you strike with this tackle. Hit short and quick, and if a good fish should pay you a visit, and break your line or tackle, never talk about it, for you would for your pains be called a "duffer only;" but be more cautious for the future.

When there is a rise of water, and it is coloured, your only chance is to fish in shallows. If it is coloured so much that you cannot see more than, say, six inches down, then select a slow swim of from two to three feet deep, on a gravelly bottom. In this state of the water the fish are close to the side, and will bite there if you stand well back, and keep quiet, for you must know that the least shake on the bank sends all the fish off in a moment. You cannot be too still when fishing a place of this sort. Fish in the same style as recommended for clear water, but a three shot float will be large enough, and you will catch them better with half the quantity of ground bait. Two, or not more than three, dew worms cut very small will be quite sufficient at a time. If you wish to fish places of this sort, you should look out when the water is low for level spots, free of rubbish. Mark them, and you will then know where to go when the water has risen. 


\section{THE GUDGEON.}

This is a well-made little fish, and is considered by most people to be excellent eating when nicely cooked. Although he is diminutive, there are many very partial to angling for him. The Londoners enjoy Gudgeon fishing very much; the ladies in particular are very clever in capturing him, and seem to take as much delight in angling for him as the gents.

Gudgeon deposit their spawn in the middle of May, seeking for that purpose a shallow stream with from eight to ten inches of water. I have seen them in thousands together at this time of the year. They seem to prefer a fine gravelly bottom for spawning to any other. I never saw them, while performing this operation, on a sandy, or a rough gravelly bottom; they select a medium between the two. They are not long in completing the process-something like five or six days will take them clean away, and then they will begin to bite in a fortnight after. Some writers are of opinion that Gudgeon spawn two or three times a year, but this is a mistake; I feel perfectly satisfied it is. No fresh water fish do or can breed twice a year, and once is quite sufficient to keep all the rivers and ponds well stocked, providing we could put a stop to the netting. This is the angler's greatest enemy, and there ought to be a law made to put it down altogether. The poachers who use this means of capturing fish, not only catch the fish in an unfair and cowardly manner, but drag weeds and spawn out, and leave them 
on the bank. I cry shame on all the netting fraternity. At all seasons it is a mean and unsportsmanlike method of catching fish, but at the spawning season it is doubly despicable.

There are writers on angling also who fancy that Gudgeon migrate at spawning time, but this I believe to be mere fancy, for they do nothing of the kind. I have watched the fish for hours together, and I could see nothing like migratory habits. The bottom they live on in spring is always close to their spawning beds, so that they do not migrate above twenty yards, if that can be called migration. In ponds, lakes, and canals, they might show synaptoms of these habits. They can live and thrive without a stream eleven months in the year, but if there is a stream to be found, be it ever so small, they will seek and find it in the spawning season. It is a continual change of water they want, and this is all they seem to migrate for. I have seen them caught with the net, half a peck at a cast, and put into a bucket of water for baits, and die almost immediately for want of a continual supply of fresh water. All they migrate for is a change of water.

The best months for Gudgeon fishing are July, August, and September, though they will bite more or less all the year round, but not so well as during the above months. But there are very few who would care about Gudgeon in the winter months, even if they were to bite every swim; the excitement they afford is not sufficient to keep one warm. If you should catch any in the winter months, you will find them much more eatable than they are in summer.

The best baits for Gudgeon are gentles and worms-the cockspur, or red worm, is the best. There are several other baits that will catch them, but none so well as these. Gentles for the early parts of summer, and worms for the latter end, and all through the winter. In my opinion the cockspur is the best bait you can fish with all the year round, for when Gudgeon will take grubs of any sort, $I$ have found they will take the worm fully as well or better than any other bait; but I would recommend you for summer fishing always to take gentles and worms 
with you, for if they should not fancy the one, perhaps the other might tempt them.

A rod ten feet long will be sufficient for Gudgeon fishing, as light as possible, with plenty of spring in it. I don't mean weak in the middle, but a rod each part of which will bear an equal share of the labour, and that will strike sharp from the top. A rod light at the top and stiff in the middle is of no use whatever, when you are fishing with a light tackle. I would recommend a two and a half inch wood reel that runs freely, for sometimes a Barbel will take a fancy to your nice red worm, and unless you have a free running reel, you know what would happen. The line recommended for Roach fishing will be just the thing to fish for Gudgeon with, but always keep sufficient on the reel in case a large fish should bite. I remember fishing a place for Gudgeon with the worm, and was agreeably surprised to find a shoal of large Perch in the swim. Two out of the first three got away in consequence of the hook being so small, but I quickly put on a larger one, and soon captured them all; then the Gudgeon came on to bite, and in a short time I caught as many as I wanted. Never use a cork float for this style of fishing, always a quill one; the smaller the better, if you can work with it. Your tackle should be fine gut, your hook for gentles No. 12, and for worms No. 10. Let your bottom shot be about nine inches from the hook, but if the stream is rapid six or seven inches will be enough.

Another person and I once laid a wager as to which of us would catch the greatest number of Gudgeon in two hours. I will here mention the plan I adopted to win the match. I took a piece of brass wire a foot long, and about the thickness of a common pin, and twisted a small noose in the middle, and another at each end of the wire. I then tied a single gut with a shot in the middle to each end. I put a No. 10 hook on each, and baited them with small cockspurs. The wire was intended to keep the tackle apart. I had a rod about eight feet long, and a piece of line the same length. I put on a small quill float, and then tied the line to the noose in the middle of the 
wire, which made my tackle complete. I then put on a pair of water boots and walked into a gentle stream to the thigh, stirring up the mud with my feet, and continuing to do so that the water might not get clear. In about a minute after I commenced a shoal of Gudgeon rushed up to the muddy water, close to my feet. I caught them like fury, often two at a time, and rarely a swim without one. In the two hours I caught ninety-six, and my opponent forty-three. If you should be hard up for Pike baits at any time, adopt this plan for catching Gudgeon, and you can take them in any quantity all through the summer, when the water is clear.

Gudgeon swims are most likely to be found on the shallow side of the river, or at the top or bottom of a deep water. You will find Gudgeon in a brisk stream with a gravelly bottom from two to four feet deep. Generally speaking, if the water be clear, three feet will be deep enough. When you have found a suitable stream, get the right depth with or without the plummet, allowing the bait to swim as close to the bottom as possible without touching. This done, take about twenty small gentles, and if you can throw them in high enough to sink in the swim do so, but if the stream is rapid put them in a piece of soft clay and drop it in at the top of the swim. Fish with a better quality than those you ground bait with. Let your hook be lapped on with white silk, and if your gentles be a good size, one will be sufficient to put on the hook, if not put on two, one to cover the shank, and the other the bend of the hook. If you are going to fish from the bank, make a cast the same distance as you have thrown the ground bait; if from a boat or punt, drop in your tackle so that it may take the exact course that the ground bait did. Keep your line behind the float and let it swim as steady as if there was no line attached to it. If the fish begin to go off the bite, throw in a few more gentles, but do not do so if they continue to bite well.

But worm fishing for Gudgeon, in my opinion, is by far the best. Every fresh water fish will take the worm, and you are obliged to keep your running line clear in case a Barbel or 
Trout, or a thumping Perch, should take a fancy to that bright red worm you are fishing with, and excellent sport it is, after killing a lot of small fry, to hook a fish that will give you a run of thirty or forty yards. The same rod and line recommended for gentle fishing will do for fishing with the worm, but the hook should be No. 10. Get two or three hundred red worms of all sorts for ground bait, and one hundred well-scoured cockspurs for the hook. Arrange your depth so that your bait will just miss the bottom, then mince five or six red worms into very small bits, and if the water is three or four feet deep, and the stream not very rapid, throw them in three yards above you, and you will find that the fish will bite about two yards below where you stand. Now take a well-scoured cockspur and put the hook in at the head and carefully thread it to an eighth of an inch of the end of the tail. You must not run the hook quite to the tail-end as that would kill the bait and take away its attraction. Allow a little bit to writhe at the point of the hook, and if you have a sharp rod and a quick eye you will catch nearly every one that bites. Let your float swim in the right style, and give the fish the same treatment as for ground baiting that I have recommended for fishing with gentles, and you cannot fail to have good sport.

THE END.

T. FORMAN, PRINTER, "GUARDIAN" OFFICE, NOTTINGHAM. 




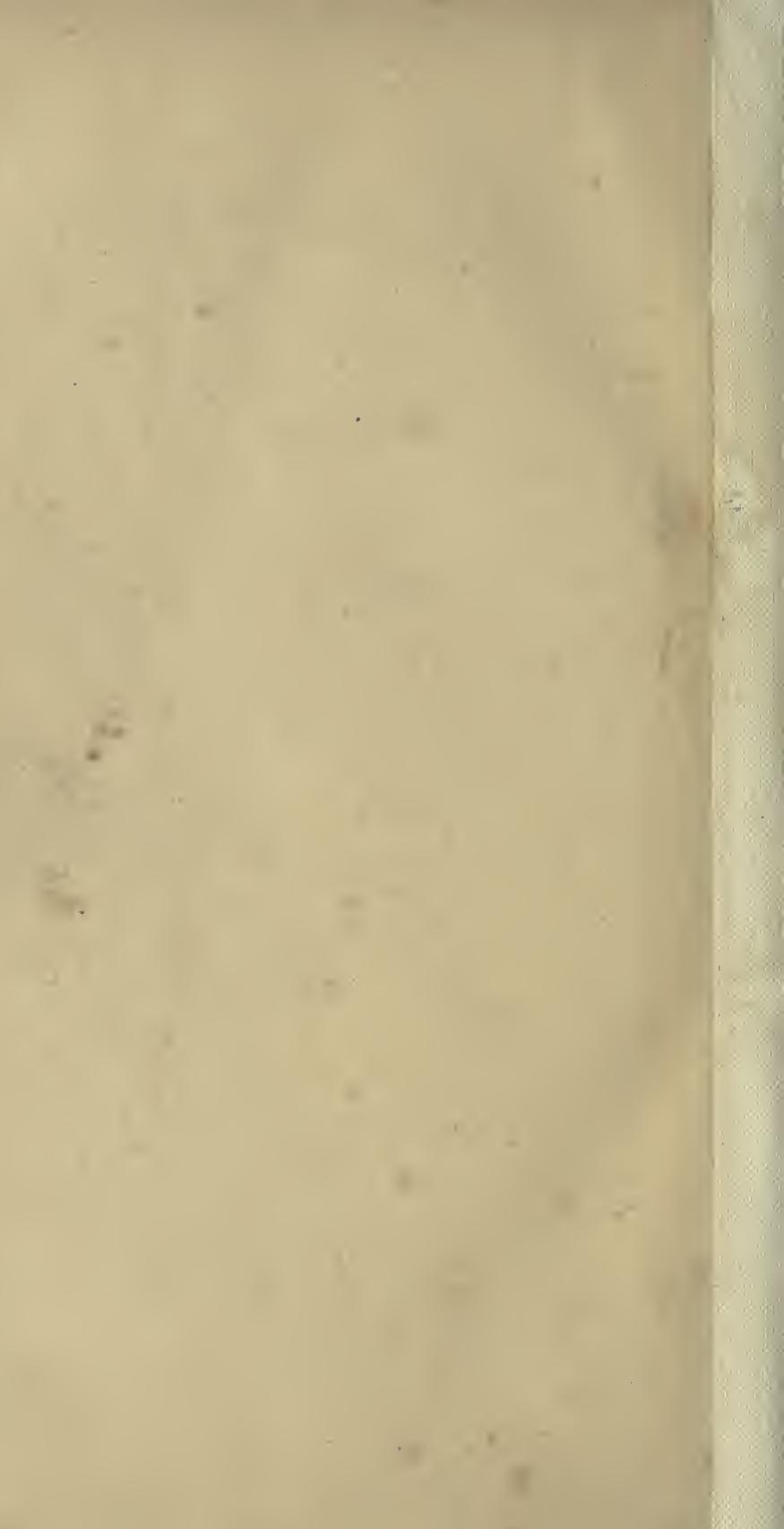


YB 10442 
